\title{
BULLETIN 41
}

\section{Precambrian Basement Terrane of South Dakota}

\author{
KELLI A. MCCORMICK
}

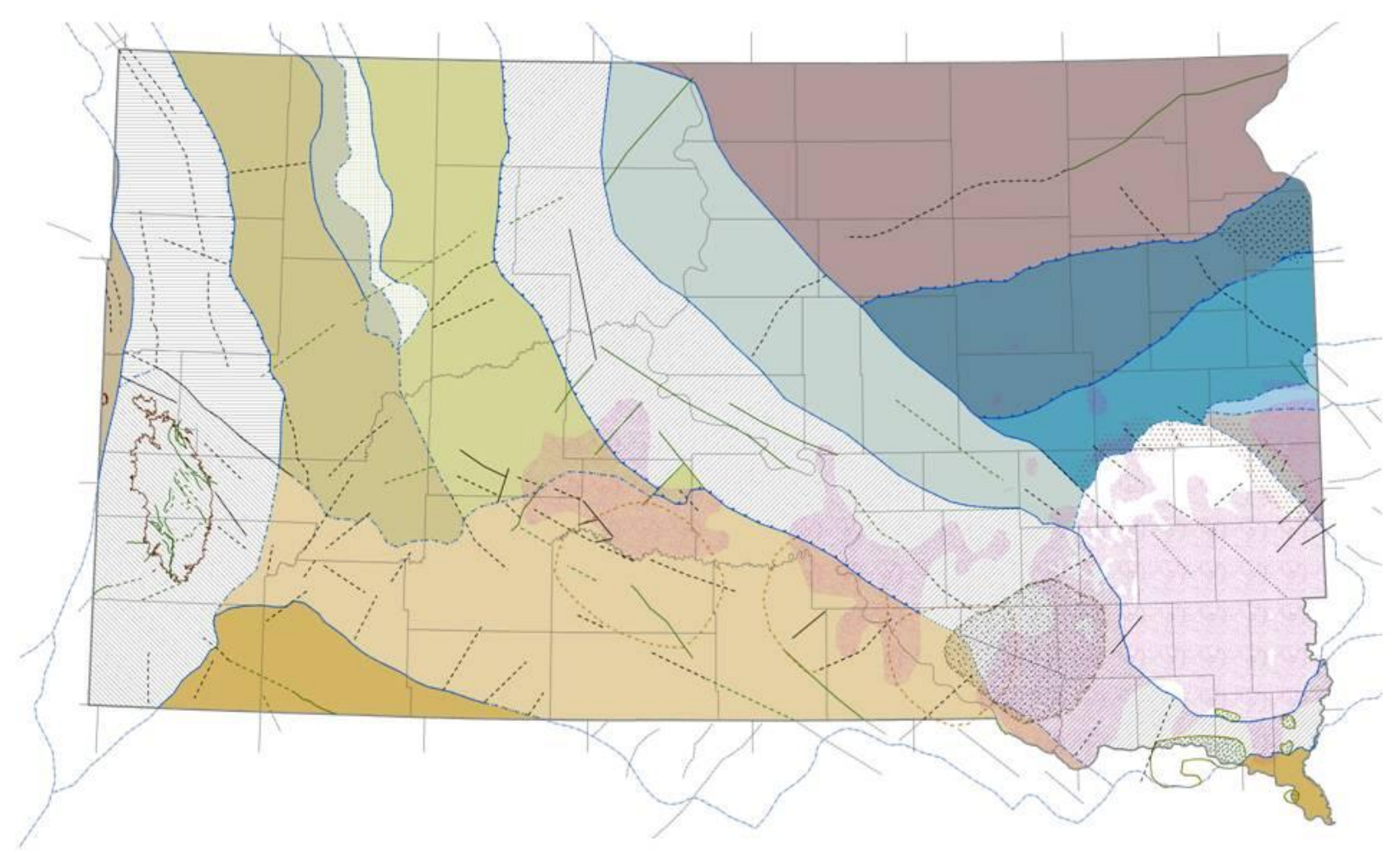

Department of Environment and Natural Resources

Geological Survey Program

Akeley-Lawrence Science Center

University of South Dakota

Vermillion, South Dakota 


\author{
GEOLOGICAL SURVEY PROGRAM \\ DEPARTMENT OF ENVIRONMENT AND NATURAL RESOURCES \\ AKELEY-LAWRENCE SCIENCE CENTER, USD \\ 414 EAST CLARK STREET \\ VERMILLION, SOUTH DAKOTA 57069-2390 \\ (605) 677-5227
}

Derric L. Iles, M.S., C.P.G.

Sarah A. Chadima, M.S., C.P.G.

Daniel E. Costello, M.S.

Timothy C. Cowman, M.S.

Brian A. Fagnan, M.S.

Dragan Filipovic, M.S.

Ann R. Jensen, B.S.

Darren J. Johnson, M.S.

Matthew T. Noonan, B.S.

Thomas B. Rich, M.S.

Layne D. Schulz, B.S.

Dennis D. Iverson

Scott W. Jensen

Ted R. Miller, B.S.

Colleen K. Odenbrett

Jeffrey J. Puthoff, B.A.

Lori L. Roinstad

Priscilla E. Young, B.S.
State Geologist

Senior Geologist

Geologist

Natural Resources Administrator

Senior Geologist

Senior Hydrologist

Senior Geologist

Geologist

Hydrologist

Senior Hydrologist

Senior Geologist

Civil Engineering Technician

Civil Engineering Technician

Civil Engineering Technician

Word Processing Supervisor

Natural Resources Technician

Cartographer

Senior Secretary

\title{
RAPID CITY REGIONAL OFFICE 2050 West Main, Suite 1 \\ RAPID CITY, SOUTH DAKOTA 57702-2493
}

(605) 394-2229

Mark D. Fahrenbach, Ph.D.

Kelli A. McCormick, Ph.D.

Joanne M. Noyes, M.S., P.E.
Senior Geologist

Senior Geologist

Senior Hydrologist 
STATE OF SOUTH DAKOTA

M. Michael Rounds, Governor

DEPARTMENT OF ENVIRONMENT AND NATURAL RESOURCES

Steven M. Pirner, Secretary

DIVISION OF FINANCIAL AND TECHNICAL ASSISTANCE

David Templeton, Director

\title{
GEOLOGICAL SURVEY PROGRAM
}

Derric L. Iles, State Geologist

Bulletin 41

\section{PRECAMBRIAN BASEMENT TERRANE OF SOUTH DAKOTA}

\author{
Kelli A. MCCORMiCK
}

Akeley-Lawrence Science Center

University of South Dakota

Vermillion, South Dakota 
This page intentionally left blank 


\section{CONTENTS}

Page

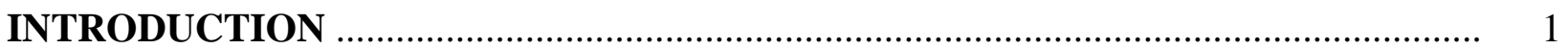

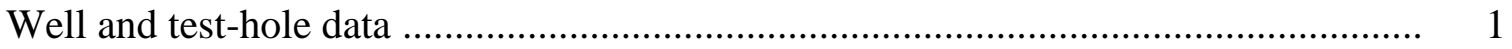

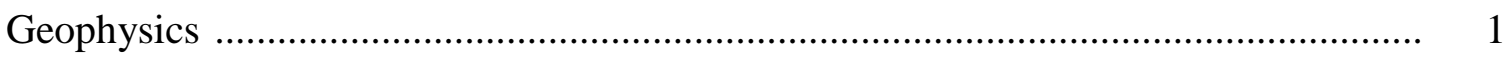

Geophysical data filters ..................................................................... 4

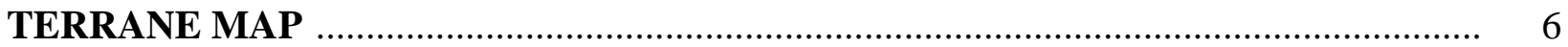

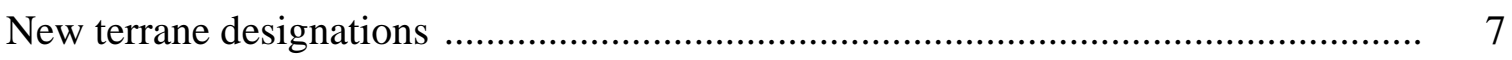

Terminology for the southern Trans-Hudson Orogen in South Dakota ...................... 7

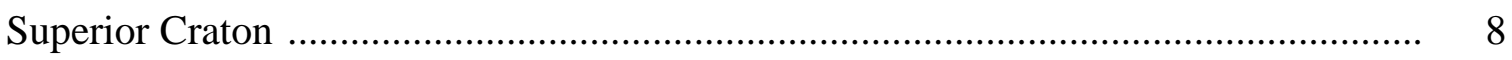

Wawa Subprovince ....................................................................... 8

Minnesota River Valley Subprovince .................................................... 10

Benson Block ........................................................................... 10

Montevideo Block ............................................................................... 10

Morton Block .................................................................................. 11

Jeffers Block(?) ........................................................................ 11

Sioux Block .............................................................................. 12

Pikwitonei-like Terrane .......................................................................... 13

Superior Boundary Zone ................................................................. 14

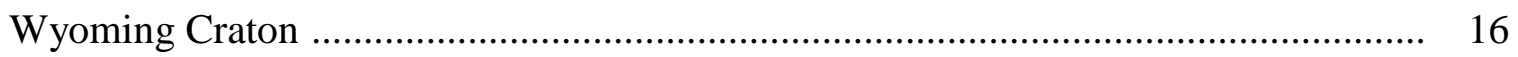

Wyoming Boundary Zone ................................................................. 16

Cedar Creek Domain ...................................................................... 17

Black Hills Domain ........................................................................ 17

Hartville Domain (Wyoming) ......................................................... 18 
TERRANE MAP - continued Page

Yavapai Terrane ….................................................................................. 19

Internides of the southern Trans-Hudson Orogen ............................................. 20

Southern Flin Flon Belt ..................................................................... 21

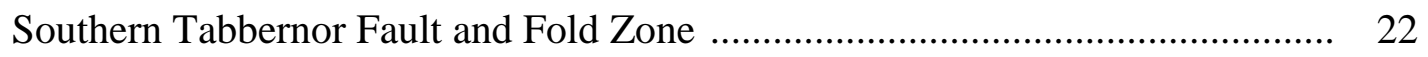

Southern Glennie Domain .............................................................. 22

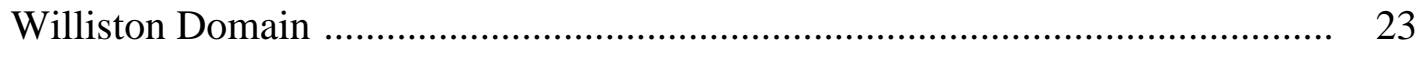

Southern Dakota Terrane ..................................................................... 24

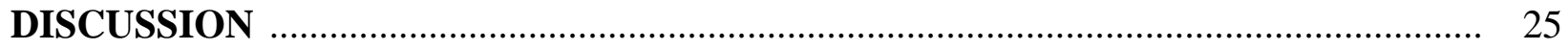

Timing of the southern Trans-Hudson Orogeny in South Dakota ............................ 25

Archean model ages and granitoid rocks of the southern

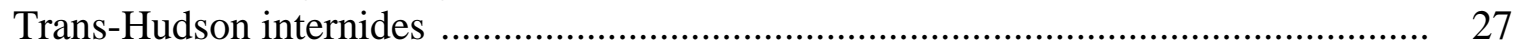

The origin of the Southern Dakota Terrane ..................................................... 27

Paleoproterozoic uranium-lead dates in the Minnesota River

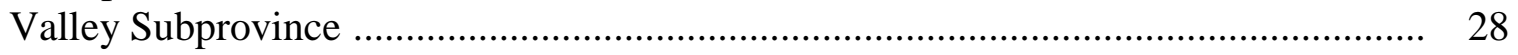

Timing of deposition of the Sioux Quartzite ...................................................... 29

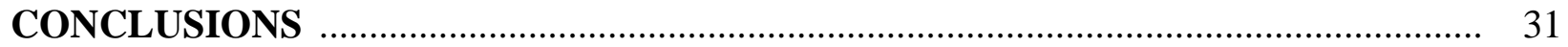

ACKNOWLEDGEMENTS …..................................................................... 31

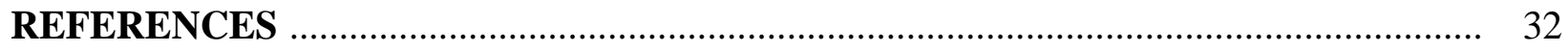




\section{ILLUSTRATIONS}

\section{PLATE}

1. Terrane map of the Precambrian basement of South Dakota External File

\section{FIGURES}

Page

1. Index map of aeromagnetic data flight line areas and spacing, and index map of gravity station locations and values in South Dakota

2. Map of the aeromagnetic data for South Dakota, with hillshade

3. Map of the complete Bouguer anomaly gravity data for South

Dakota, with hillshade

4. Map of the first horizontal derivative of the aeromagnetic data

for South Dakota, with hillshade

5. Map of the first horizontal derivative of the gravity data for South

Dakota, with hillshade

6. Map of the aspect of the aeromagnetic first horizontal derivative for

South Dakota

7. Map showing state boundaries and names, and county boundaries and

names for southeast South Dakota, northeast Nebraska, and northwest Iowa

8. Simplified terrane map of the Trans-Hudson Orogen on the Canadian

Shield, Saskatchewan and Manitoba, Canada

9. A schematic of the Wyoming-Superior closure and Yavapai orogenic event starting with subduction under the Wyoming and Superior Cratons as the two cratons move toward each other (A) through closure of the WyomingSuperior suture and subsequent collision of the Yavapai Orogeny $(B, C)$, and ending with post orogenic intrusions (D)

\section{TABLE}

1. Compilation of radiometric dates of Precambrian rocks

in South Dakota 
This page intentionally left blank 


\section{INTRODUCTION}

The "Terrane Map of the Precambrian Basement of South Dakota" (pl. 1) is based on a variety of data types and sources. These types and sources of data include a compilation of well and test-hole data (basement rock type and depth to basement data), the elevation contour map of the Precambrian surface in South Dakota (McCormick, 2010), existing geophysics (magnetic and gravity data), previously published basement maps of South Dakota and surrounding states, and published radiometric dates.

\section{Well and Test-Hole Data}

The drill-hole database used in this study consists of 7,523 drill holes. Of these data, 4,830 drill holes intersected Precambrian basement rock and 2,693 drill holes did not. This database was created by searching published maps and reports, unpublished data, and internal and online databases for holes that reached the Precambrian basement or were considered fairly deep holes in areas where no Precambrian intersects are known to exist (which is the case for several South Dakota counties). These non-intersect holes provide constraints on depth to basement. The drill holes to Precambrian basement presented here (pl. 1) are a subset of the 7,523-hole database for which a specific rock type (such as granite or schist) is identified. The complete well and testhole database, as well as the subset of data displayed on this map, are available for download from the Geological Survey Program website.

\section{Geophysics}

The geophysical data used were mainly aeromagnetic and gravity data compiled by the U.S. Geological Survey. These data are available for download at the Crustal Imaging and Characterization Team geophysical data products website which can be found at the following web address: http://crustal.cr.usgs.gov/geophysics/index.html. Ground magnetic data collected in the 1950s by the South Dakota Geological Survey (Petsch, 1967) were also used in the creation of the terrane map.

The U.S. Geological Survey aeromagnetic data (Kucks and Hill, 2002; figs. 1 and 2) were mostly NURE (National Uranium Resource Evaluation) data, flown at a flight line spacing of 4,800 to 9,600 meters (3-6 miles). Because the collection of magnetic data was not the primary objective in the design of the NURE surveys, these data are subject to certain limitations (Kucks and Hill, 2002). The wide spacing between flight lines flown at low altitudes over surface rock units having high magnetizations causes anomalies with short spatial wavelengths to be elongated between flight lines, producing lineations perpendicular to the flight-line direction and "pearl string" anomalies along the flight line. Problems related to the reduction of navigation control (that is, the adjustment of navigation reference point from the aircraft to the magnetometer) and inconsistent datum levels between surveys cause herringbone features which can be observed within and at the boundaries of $1^{\circ} \times 2^{\circ}$ quadrangles. 

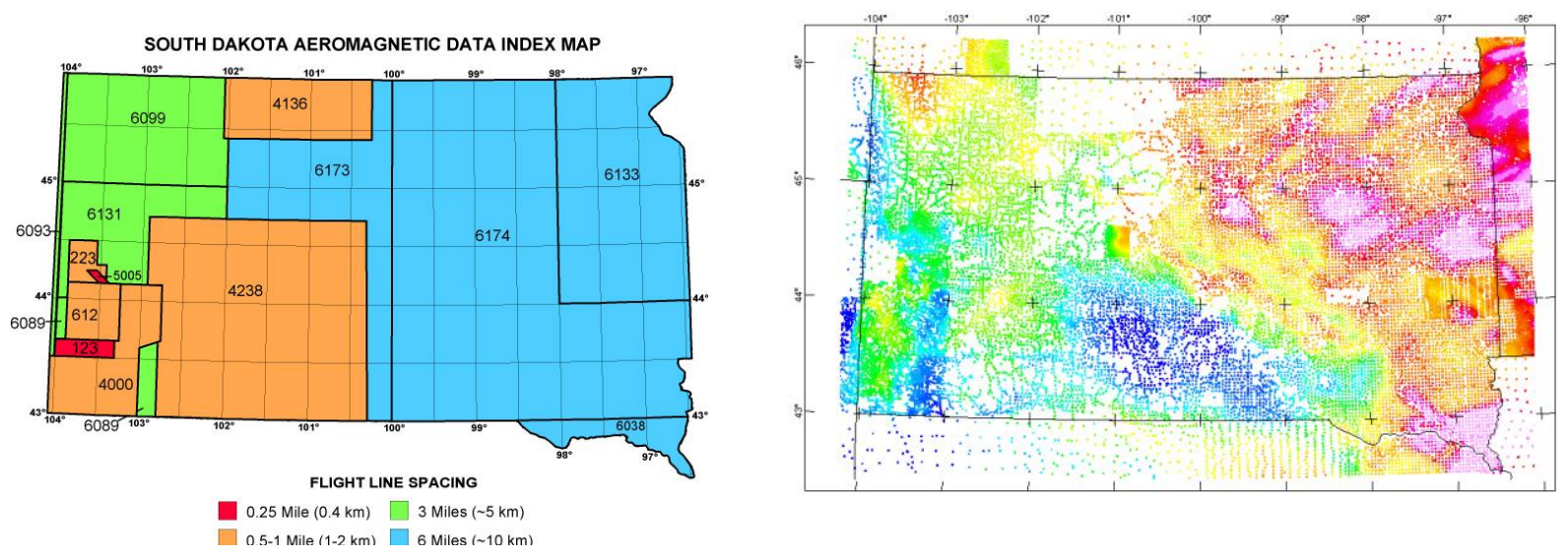

Modified from Kucks and Hill (2002)

Figure 1. Index map of aeromagnetic data flight line areas and spacing, and index map of gravity station locations and values in South Dakota.

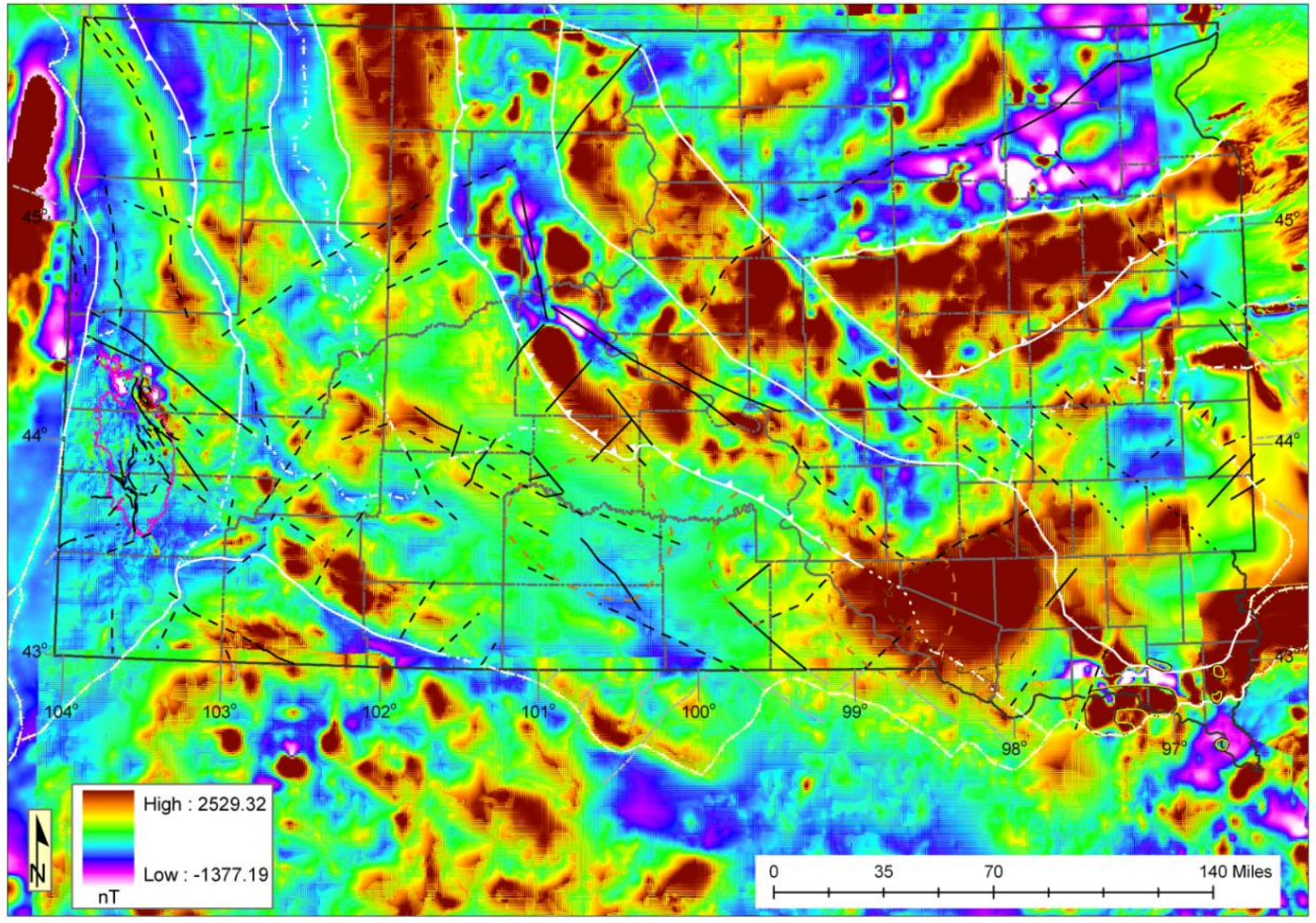

Modified from Kucks and Hill (2002)

Map shows county boundaries, outline of the Precambrian outcrop area, and basement structures (see pl. 1) Black lines = faults; lines dashed where uncertain, dotted where inferred White lines $=$ terrane boundaries and suture zones $\mathrm{nT}=$ nanotesla

Figure 2. Map of the aeromagnetic data for South Dakota, with hillshade. 
The South Dakota gravity data (Kucks and Hill, 2002; figs. 1 and 3) used in this study were mainly the complete Bouguer gravity data, though the isostatic gravity data were also considered. The gravity data were generated from 28,514 gravity station measurements in and adjacent to the state of South Dakota. The data were converted to a 1,000-meter grid (Kucks and Hill, 2002).

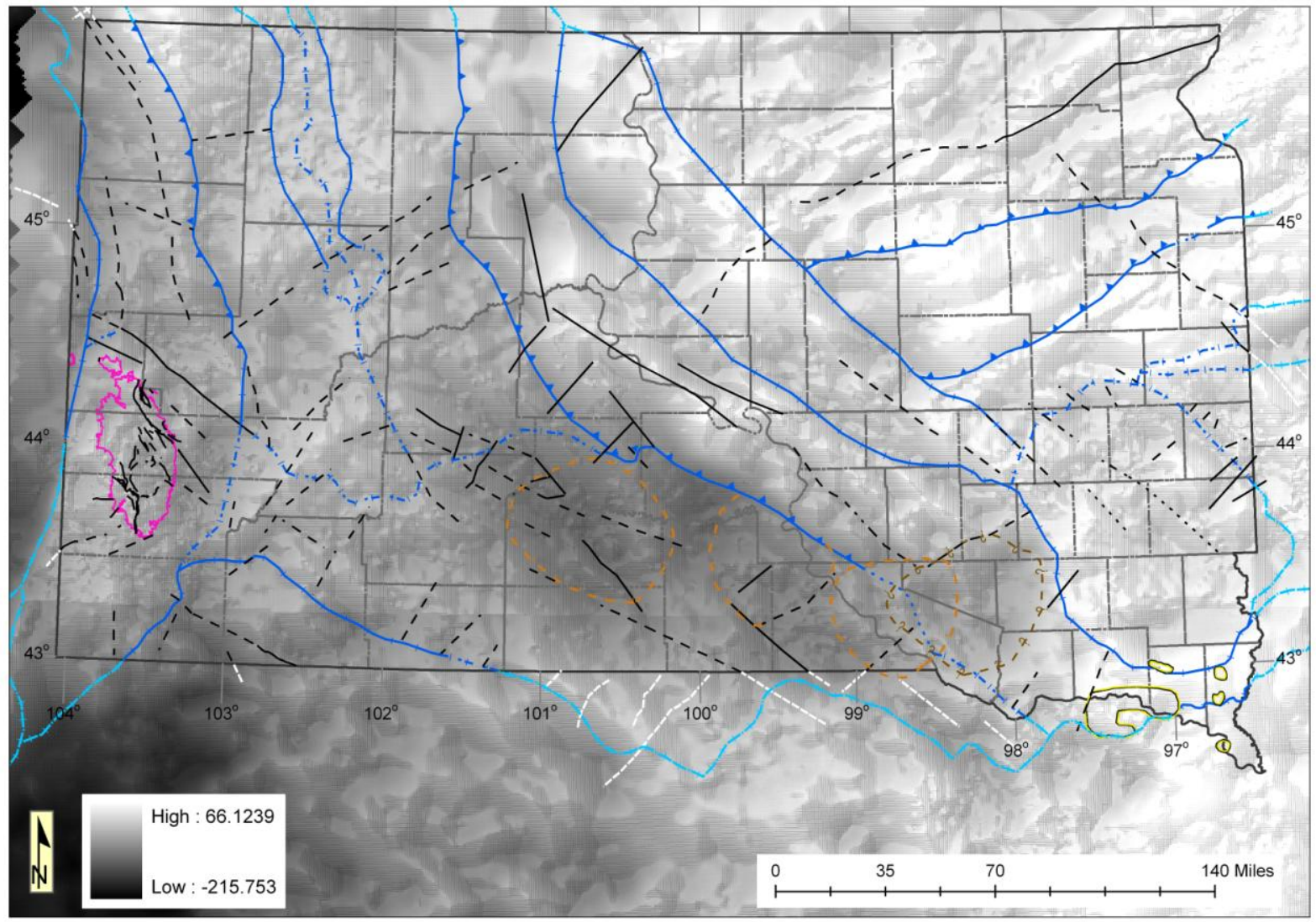

Modified from Kucks and Hill (2002)

Map shows county boundaries, outline of the Precambrian outcrop area, and basement structures (see pl. 1) Black lines = faults; lines dashed where uncertain, dotted where inferred Blue lines $=$ terrane boundaries and suture zones $\mathrm{mGal}=$ milligal

Figure 3. Map of the complete Bouguer anomaly gravity data for South Dakota, with hillshade.

No reprocessing of original data was carried out in this study. For the U.S. Geological Survey data, the 1,000-meter grid spacing that was used by the U.S. Geological Survey was kept for each data set. The aeromagnetic and complete Bouguer anomaly maps for South Dakota are presented in figures 2 and 3 , respectively. 
Hillshading, an image processing filter, and horizontal derivatives were the main filters applied to the aeromagnetic and gravity data for South Dakota. Both of these filters were applied using ArcGIS (an ESRI ${ }^{\mathrm{TM}}$ product). The illumination direction for the hillshading is $315^{\circ}$ (from the northwest), measured clockwise from $0^{\circ}$ at due north.

Spatial analyst was used in ArcGIS to calculate the slopes of the aeromagnetic and gravity grids (figs. 4 and 5). These slopes are horizontal derivatives of each grid. Horizontal derivatives yield amplitudes of the horizontal gradients and enhance edges of features (Cooper and Cowan, 2006).

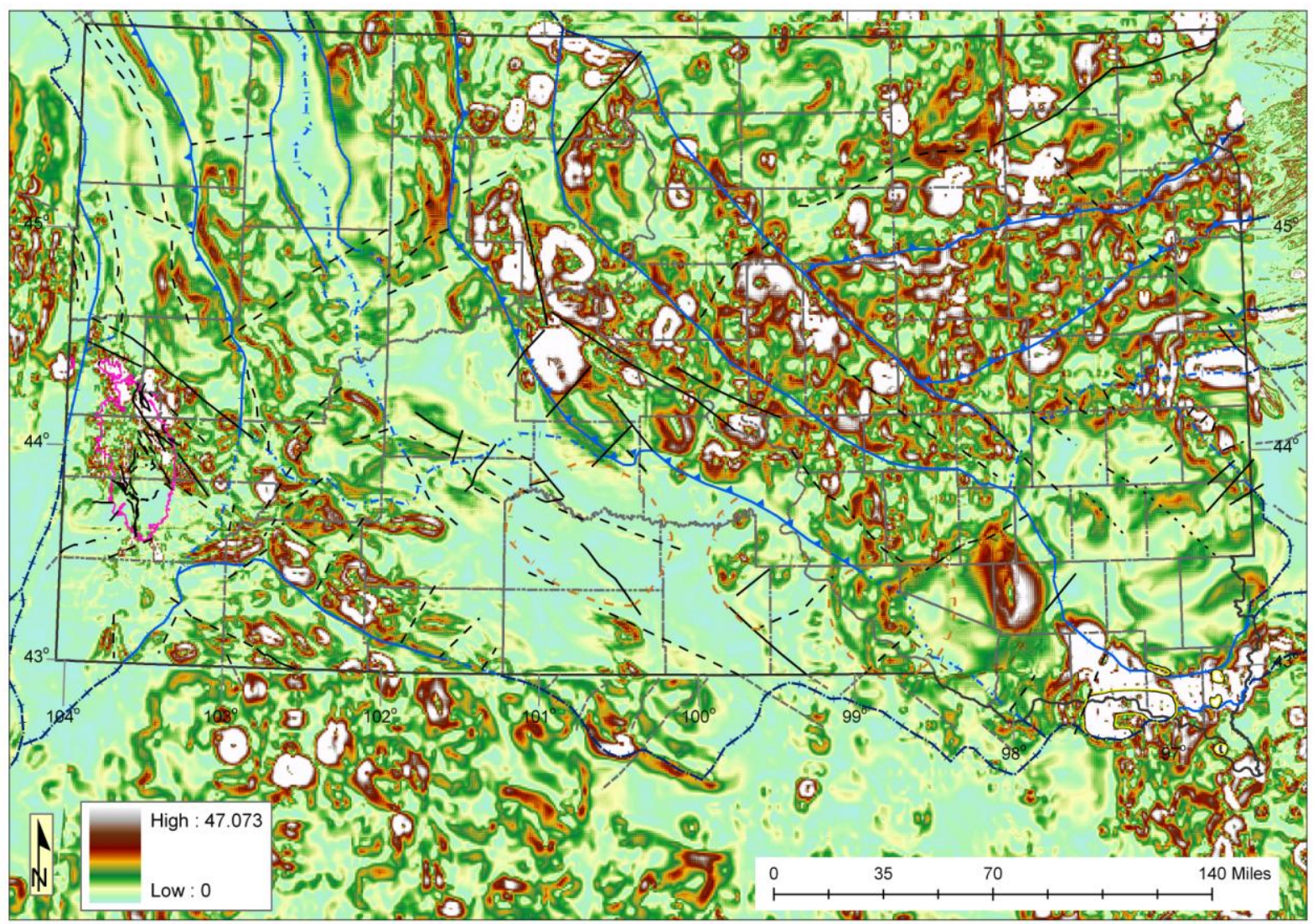

Map shows county boundaries, outline of the Precambrian outcrop area, and basement structures (see pl. 1) Black lines = faults; lines dashed where uncertain, dotted where inferred Blue lines = terrane boundaries and suture zones

Figure 4. Map of the first horizontal derivative of the aeromagnetic data for South Dakota, with hillshade. 


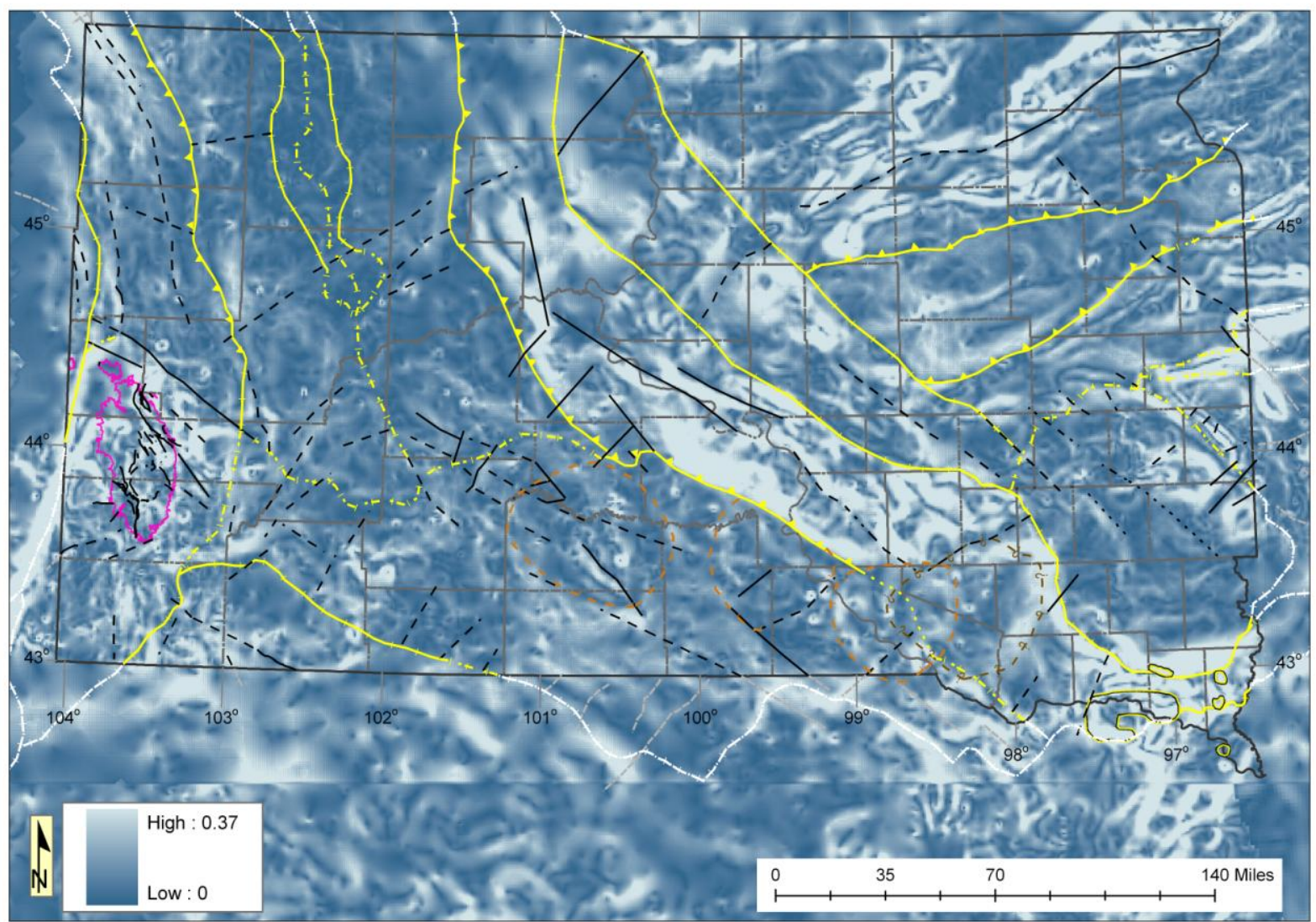

Map shows county boundaries, outline of the Precambrian outcrop area, and basement structures (see pl. 1) Black lines = faults; lines dashed where uncertain, dotted where inferred Yellow lines $=$ structural boundaries

Figure 5. Map of the first horizontal derivative of the gravity data for South Dakota, with hillshade.

Another enhancement tool used in ArcGIS was the aspect tool. The aspect yields an azimuth or direction (downslope) of the maximum rate of change in value from each cell to its neighbors (ArcGIS version 9.3). Zero azimuth is north. The aspect of the first horizontal derivative of the aeromagnetic data was used to enhance the texture of certain terranes and refine terrane boundaries (fig. 6).

Basement structures (faults, structural boundaries between terranes, and other features) were located based on the combination of filtered data, including a color-coded gravity versus magnetic values map created by Dr. Edward Duke (oral commun., 2009). 


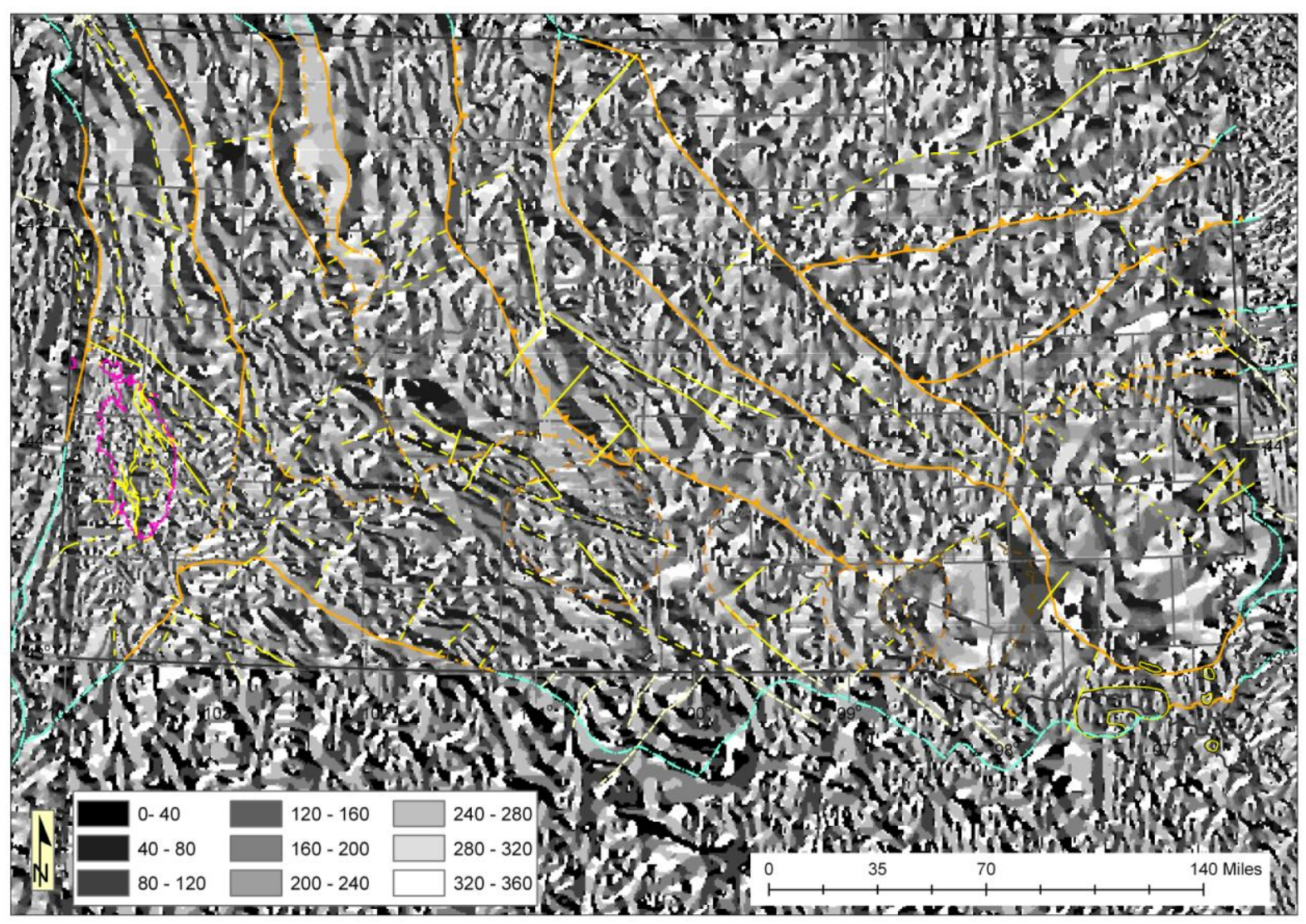

Map shows county boundaries, outline of the Precambrian outcrop area, and basement structures (see pl. 1)

Yellow lines = faults; lines dashed where uncertain, dotted where inferred

Orange lines $=$ structural boundaries

Figure 6. Map of the aspect of the aeromagnetic first horizontal derivative for South Dakota.

\section{TERRANE MAP}

Plate 1 presents an updated interpretation of the Precambrian basement of South Dakota, and includes structural boundaries, other major faults, drill holes intersecting basement rock, and published radiometric dates. Structural boundaries separate different terranes. Where dip direction along structural boundaries is known, it is indicated with carets on the overriding plate. Faults and structural boundaries are interpreted mainly from the geophysical data, with a few exceptions where drilling has revealed displacement in specific areas.

The term "terrane" is used here to refer to oceanic or continental crust that has geologic history separate from adjacent terranes. Structural boundaries separate the different terranes. The term "domain" as applied to new names defined on this map, is used to indicate an area of a terrane that has a different geophysical character than adjacent areas, suggesting a structural boundary is present. For example, the Wyoming Boundary Zone is separated into domains based on distinctively different geophysical characteristics. The term "block" is carried over from 
Minnesota terminology and is used as part of the terrane names in eastern South Dakota. Other terms are carried southward from the Canadian Shield.

\section{$\underline{\text { New Terrane Designations }}$}

New interpretations presented in this study (pl. 1) include the concept that the Wyoming Boundary Zone (Lewry and Collerson, 1990) can be separated into three domains in and around South Dakota: the Cedar Creek Domain, the Black Hills Domain (here defined as a considerably more restricted area than has been previously published by Sims and others, 1991), and a postulated Hartville Domain. A new domain has been designated to the east of the Wyoming Boundary Zone, the Williston Domain. A new designation, the Southern Dakota Terrane, is proposed in this study for the hypothesized magmatic terrane just north of the Yavapai boundary (Klasner and King, 1990). This terrane encompasses the low gravity zone in south-central South Dakota (fig. 3) and the positive magnetic anomalies to the east, west, and south of the gravity low (fig. 2). Finally, a new designation, the Sioux Block, is proposed for the southernmost section of the Minnesota River Valley Subprovince in South Dakota.

\section{Terminology for the Southern Trans-Hudson Orogen in South Dakota}

The term "internide" is used to refer to terranes that comprise the internal part of an orogenic belt. In this study, internides refer to the terranes that make up the Wyoming-Superior suture zone (i.e., the southern extension of the Trans-Hudson terrane).

Numerous terms have been used to describe the Trans-Hudson internides that extend through North and South Dakota. In Canada, the Reindeer zone is used to encompass the region of internides that is covered by Paleozoic (and younger) rocks (Lewry and others, 1990). Dutch and Nielson (1990) have proposed the term "Dakota segment" to encompass the Trans-Hudson internides from the Canadian Shield to the Yavapai boundary. Southern Trans-Hudson has been used in the literature as well (Holm, 1999).

It is common practice in the literature to extend orogeny names beyond the original type areas in situations where data support a correlation of orogenic events. Examples of this include the Yavapai Orogeny, originally recognized in Arizona (Karlstrom and Bowring, 1988) and extended into the northern mid-continent (Holm and others, 2007; Van Schmus and others, 2007), and the Penokean Orogeny, originally recognized in Wisconsin (Van Schmus, 1980) and later extended into Minnesota (Holm and others, 2007; Schulz and Cannon, 2007). With this in mind, and despite the apparent time-transgressive nature of the suturing of the Wyoming and Superior Cratons, the term "southern Trans-Hudson" is used in this study to refer to the terranes within the Wyoming-Superior suture in South Dakota (but see the DISCUSSION section for an in-depth consideration of the timing of closure). 


\section{$\underline{\text { Superior Craton }}$}

The Archean Superior Craton proper encompasses that part of the craton in South Dakota that is defined as having undergone little or no modification by collision with the Wyoming Craton to the west or by the accretion of island arcs during the Yavapai Orogeny to the south.

The Archean Superior Craton comprises the basement in the eastern side of South Dakota (pl. 1). Based on work in Minnesota, the subdivisions of the Superior Craton are the Wawa Subprovince and the Minnesota River Valley Subprovince (Sims and others, 1993; Southwick and Chandler, 1996; Schmitz and others, 2006). The boundary between these two subprovinces is the Great Lakes Tectonic Zone. The Great Lakes Tectonic Zone itself, which separates the Wawa and Minnesota River Valley Subprovinces, is a north-dipping suture (Southwick and Chandler, 1996; Chandler and others, 2007). The collision that formed this suture is interpreted to have occurred ca 2,600 Ma, with associated extensive emplacement of granites into parts of the Minnesota River Valley Subprovince (Southwick and Chandler, 1996; Schmitz and others, 2006; Holm and others, 2007).

In Minnesota, the Minnesota River Valley Subprovince is further divided, from north to south, into the Benson, Montevideo, Morton, and Jeffers Blocks, respectively (Southwick and Chandler, 1996).

\section{Wawa Subprovince}

The Wawa Subprovince includes a significant area of moderate gravity and relatively low magnetic values (figs. 2 and 3). The bands of lower gravity and magnetic intensity likely correspond to the metasedimentary basin fill in this granite-greenstone terrane (Reed and others, 1993; this study). These granite-greenstone terranes typically consist of sub-vertical belts of metavolcanic and metasedimentary rocks, including banded iron formation, and domal- to elongate-granite batholiths (Reed and others, 1993; Chandler and others, 2007). The Wawa Subprovince is mainly Late Archean in age, ca 2,750-2,600 Ma (Williams, 1990; Holm and others, 2007). In South Dakota, this terrane has a distinctive southwest-northeast trending fabric.

Rock types intersected in drill holes in this terrane include granite, schist, and banded iron formation. Radiometric dates for two rocks from the Wawa Subprovince in South Dakota have been published (table 1). A quartz monzonite drilled in Marshall County yields a Sm-Nd whole rock date of 2,720 Ma (Goldich and others, 1966; Sims and others, 1991). A staurolite-biotite schist drilled in Day County (about 0.25 miles from a hole that intersected banded iron formation) yields an $\mathrm{Rb}-\mathrm{Sr}$ whole rock date of 2,560 $555 \mathrm{Ma}$ (Richards and others, 1986; Sims and others, 1991). The Sm-Nd whole rock date for the quartz monzonite is close to the age range given for the Wawa terrane in the Lake Superior region (Williams, 1990; Holm and others, 2007). The Rb-Sr date should be considered a minimum age, and, in fact, may have been reset during collision with the Minnesota River Valley Subprovince along its southern margin. 
Table 1. Compilation of radiometric dates of Precambrian rocks in South Dakota

\begin{tabular}{|c|c|c|c|c|c|c|c|c|c|c|c|c|}
\hline \multirow{3}{*}{ Terrane } & \multirow{3}{*}{ County } & \multirow{3}{*}{ Reported rock type } & \multicolumn{9}{|c|}{ Type of radiometric analysis ${ }^{1}$ and age in millions of years before present } & \multirow{3}{*}{$\begin{array}{l}\text { Data } \\
\text { sources }^{2}\end{array}$} \\
\hline & & & \multicolumn{3}{|c|}{ Rb-Sr } & \multirow{2}{*}{$\begin{array}{c}\begin{array}{c}\mathrm{U}-\mathrm{Pb} \\
\mathrm{Pb}-\mathrm{Pb}\end{array} \\
\text { Zircon }\end{array}$} & \multicolumn{2}{|c|}{ Sm-Nd } & \multirow{2}{*}{$\frac{\text { Ar-Ar }}{\text { Hornblende or biotite }}$} & \multirow{2}{*}{$\begin{array}{c}\text { K-Ar } \\
\text { Whole rock or biotite }\end{array}$} & \multirow{2}{*}{ Other } & \\
\hline & & & Whole rock & Feldspar & Biotite & & Whole rock & Model age & & & & \\
\hline \multirow{2}{*}{$\begin{array}{c}\text { Wawa } \\
\text { Subprovince }\end{array}$} & Marshall & Quartz monzonite & 2,490 & 2,350 & 2,350 & --- & 2,720 & --- & --- & 2,400 (biotite) & --- & 1,2 \\
\hline & Day & $\begin{array}{c}\text { Staurolite-biotite } \\
\text { schist }\end{array}$ & $2,560 \pm 55$ & --- & 2,440 & --- & --- & --- & --- & 2,440 (biotite) & --- & 2,4 \\
\hline Benson Block & Grant & Granite & & $\begin{array}{l}2,588, \\
2,723\end{array}$ & & & & & & & & \\
\hline \multirow{2}{*}{$\begin{array}{l}\text { Montevideo } \\
\text { Block }\end{array}$} & Sanborn & Altered rhyolite & 1,698 & -- & --- & --- & --- & --- & --- & 1,680 (whole rock) & --- & 1,2 \\
\hline & Beadle & $\begin{array}{c}\text { Chlorite-hornblende } \\
\text { gneiss } \\
\end{array}$ & --- & --- & --- & --- & --- & --- & 2,449 & --- & --- & 6 \\
\hline Jeffers Block(?) & Moody & Microgranite & --- & --- & --- & $1,790 \pm 13$ & --- & 2,570 & --- & --- & -- & 5 \\
\hline \multirow{2}{*}{ Sioux Block } & Kingsbury & Quartz latite & 1,698 & --- & --- & --- & --- & --- & --- & --- & --- & 1,2 \\
\hline & Moody & Meta-rhyolite & --- & --- & --- & $1,828 \pm 8$ & --- & 2,590 & --- & --- & --- & 5 \\
\hline \multirow{3}{*}{$\begin{array}{l}\text { Pikwitonei-like } \\
\text { Terrane }\end{array}$} & Sanborn & Biotite gneiss & $\begin{array}{c}2,710 \\
\text { calculated }\end{array}$ & --- & --- & --- & 2,720 & --- & --- & --- & $\begin{array}{c}2,100 \pm 40 \mathrm{Rb}-\mathrm{Sr} \\
\text { isochron }\end{array}$ & 3 \\
\hline & Jerauld & Biotite-garnet gneiss & 2,520 & --- & 1,800 & --- & 2,830 & --- & 1,869 (biotite) & --- & $\begin{array}{l}2,490 \mathrm{Sm}-\mathrm{Nd} \\
\text { biotite-garnet }\end{array}$ & 3,6 \\
\hline & Walworth & $\begin{array}{c}\text { Granite and biotite } \\
\text { schist }\end{array}$ & --- & --- & 1,750 & --- & --- & --- & --- & --- & -- & 1,2 (cuttings) \\
\hline \multirow{3}{*}{ Yavapai } & Clay & Granite & --- & --- & --- & $1,762 \pm 28$ & --- & 2,080 & --- & --- & --- & 5 \\
\hline & Union & Metagabbro & --- & --- & --- & $1,733 \pm 2$ & --- & 2,170 & $\begin{array}{c}1,650 \pm 2 \text { (hornblende) } \\
1,562 \pm 4 \text { (biotite) } \\
\end{array}$ & -- & -- & 5 \\
\hline & Union & Granite & --- & 1,460 & --- & --- & --- & --- & --- & --- & --- & 1,2 (cuttings) \\
\hline \multirow{3}{*}{$\begin{array}{c}\text { Superior } \\
\text { Boundary Zone }\end{array}$} & Stanley & Quartz monzonite & --- & 1,660 & --- & --- & --- & -- & --- & --- & --- & 1, 2 (cuttings) \\
\hline & Aurora & Granite or gneiss & 1,930 & --- & --- & $\begin{array}{c}1,680 \\
\text { discordant }\end{array}$ & --- & --- & --- & --- & --- & 3 \\
\hline & Davison & Granodiorite & --- & --- & --- & $1,871 \pm 16$ & 1,870 & 2,550 & --- & --- & --- & 5 \\
\hline $\begin{array}{l}\text { Cedar Creek } \\
\text { Domain } \\
\end{array}$ & Butte & Granitic gneiss & $\begin{array}{c}1,729, \\
1,710,1,630 \\
\end{array}$ & --- & --- & --- & --- & 3,050 & --- & --- & --- & 1,3 \\
\hline $\begin{array}{c}\text { Black Hills } \\
\text { Domain }\end{array}$ & Fall River & Granite & -- & --- & 1,490 & --- & --- & --- & --- & --- & --- & 1,2 (cuttings) \\
\hline \multirow{2}{*}{$\begin{array}{l}\text { Southern Flin } \\
\text { Flon Belt }\end{array}$} & Perkins & Granite & --- & 1,790 & --- & --- & --- & --- & --- & --- & --- & 1,2 (cuttings) \\
\hline & Perkins & Granite & --- & 1,810 & --- & --- & --- & --- & --- & --- & --- & 1, 2 (cuttings) \\
\hline \multirow{3}{*}{$\begin{array}{l}\text { Southern } \\
\text { Dakota Terrane }\end{array}$} & Gregory & Granite or rhyolite & 1,550 & --- & --- & $\begin{array}{c}1,780-1,790 \\
\text { discordant }\end{array}$ & -- & -- & --- & -- & -- & 3 (cuttings) \\
\hline & Tripp & Quartz monzonite & --- & 1,480 & --- & --- & --- & --- & --- & --- & --- & 1,2 (cuttings) \\
\hline & Tripp & Quartz monzonite & --- & 1,510 & --- & --- & --- & --- & --- & --- & --- & 1,2 (cuttings) \\
\hline
\end{tabular}

${ }^{1} \mathrm{Rb}-\mathrm{Sr}=$ Rubidium-Strontium

$\mathrm{U}-\mathrm{Pb}=$ Uranium-Lead
$\mathrm{Pb}-\mathrm{Pb}=$ Lead-Lead

$\mathrm{SM}-\mathrm{Nd}=$ = Samarium-Neodymium

$\mathrm{Ar}-\mathrm{Ar}=$ Argon-Argon
$\mathrm{K}$-Ar $=$ Potassium-Argon

${ }^{2}$ Data sources: $1=$ Goldich and others (1966); dates recalculated using a decay constant of $1.42 \times 10^{-11} / \mathrm{yr}$

$2=$ Sims and others $(1991)$
$3=$ unpublished U.S. Geological Survey data reported in Sims and others (1991)

$4=$ Richards and others (1986)
$5=$ Van Schmus and others (2007)

See plate 1 for locations of radiometric dates

$6=$ Hull and others (2009)

All samples are from core except where noted as cuttings 


\section{Minnesota River Valley Subprovince}

The Minnesota River Valley Subprovince is dominated by ca 3,600-3,400 Ma gneisses (Sims and Peterman, 1981; Bickford and others, 2006; Schmitz and others, 2006; Holm and others, 2007), which are considerably older than the granite-greenstones of the Wawa Subprovince north of the Great Lakes Tectonic Zone. The Great Lakes Tectonic Zone that separates the Wawa and Minnesota River Valley Subprovinces is interpreted to be north dipping.

In Minnesota, the Minnesota River Valley Subprovince has been divided into the Benson, Montevideo, Morton, and Jeffers Blocks, from north to south, respectively. The sutures between the Benson and Montevideo Blocks (the Appleton geophysical lineament) and between the Montevideo and Morton Blocks (the Yellow Medicine Shear Zone) are also interpreted to be north dipping, based on geophysical models (Southwick and Chandler, 1996). All of these terranes are dominated by Archean gneisses, although the Benson and Jeffers Blocks are thought to contain less gneiss and a greater diversity of syntectonic and late-tectonic plutons (Southwick and Chandler, 1996).

\section{BENSON BLOCK}

The Benson Block is characterized by very broad, irregular positive magnetic anomalies and very broad gravity highs (figs. 2 and 3). The elliptical features on the first horizontal derivative gravity map (fig. 5) may outline these plutons. In South Dakota, the Milbank Granite is likely one such syntectonic pluton. Goldich and others (1966) dated two Milbank quarry samples by $\mathrm{Rb}-\mathrm{Sr}$ measurements in feldspar. Their analyses yielded radiometric ages of 2,588 and 2,723 Ma (table 1; as recalculated in this study using the decay rate, $\lambda=1.42 \times 10^{-11} / \mathrm{yr}$ ).

The western boundary of the Benson Block is a major northwest-striking fault or shear that extends at least from the Great Lakes Tectonic Zone south to the Appleton geophysical lineament. To the west of this shear, within the Pikwitonei-like Terrane, the northern boundary of the Benson Block has been tentatively identified (dashed fault running through western Faulk, southeastern Potter, and across Sully Counties on pl. 1), but is displaced to the north relative to the main block east of the boundary.

Rock types intersected in drill holes within this terrane are mainly granite, but also include schist, felsic gneiss, and quartzite which is described to overlie granite or granodiorite in three holes. No radiometric dates other than those from Milbank Granite have been published for rocks within the Benson Block in South Dakota.

\section{MONTEVIDEO BLOCK}

The Montevideo Block is bounded on the north by the Appleton geophysical lineament (pl.1). The Appleton geophysical lineament is located along the magnetic discontinuity separating the fairly highly magnetic rocks in the Benson Block from the variably magnetic rocks in this terrane. The southern boundary of the Montevideo Block in Minnesota is the 
Yellow Medicine Shear Zone. In South Dakota, this shear zone becomes less well-defined progressively westward. The Yellow Medicine Shear Zone is located at the southern margin of a magnetic low. At the state line, gradient maxima on the horizontal derivative magnetic and gravity maps (figs. 4 and 5) complicate the correlation of this terrane into South Dakota, but the magnetic low continues to the west and it is assumed the Yellow Medicine Shear Zone does, as well. Westward into Kingsbury County, the magnetic low dies out and it is unclear as to whether the Yellow Medicine Shear Zone continues to define the southern margin of the Montevideo Block to the west.

The Montevideo Block consists mainly of granitic rocks in South Dakota based on the little available drill-hole data, which is consistent with the general character of the Minnesota River Valley Subprovince. Sioux Quartzite overlies parts of the granitic rocks within the terrane; a greenstone and a rhyolite also have been intersected in drill holes. Radiometric ages of the rhyolite, which was intersected on the Joseph Grassel farm in Sanborn County (Lee, 1957), yields an $\mathrm{Rb}-\mathrm{Sr}$ whole rock date of 1,698 Ma (table 1, Goldich and others, 1966; Sims and others, 1991).

\section{MORTON BLOCK}

South of the Yellow Medicine Shear Zone in South Dakota, difficulties continue in attempting to carry recognized Minnesota structures and terranes into South Dakota. In Minnesota, the terrane immediately to the south of the Yellow Medicine Shear Zone is the Morton Block. The Morton Block is extended into South Dakota (pl. 1) but numerous major faults seem to typify the terrane in South Dakota, which appears not to be a particular feature of this block in Minnesota. It is also unclear what the nature of the boundary between the Morton and Jeffers Blocks is in Minnesota, resulting in a great degree of uncertainty in the correlation into South Dakota.

In Minnesota, the northern part of the Morton Block consists of a low-grade greenstone belt lithic association, the Taunton Belt, which includes minor mafic and ultramafic igneous rocks (Southwick and Chandler, 1996; Schmitz and others, 2006). The continuation of the Taunton Belt into South Dakota is uncertain. Only one drill hole to the Precambrian basement occurs in the area (a schist intersect), so the existence of the Taunton Belt is possible, but unproven. The faults interpreted to be present in this block in South Dakota may have modified or otherwise removed this belt.

The only basement rocks intersected in the Morton Block in South Dakota are a schist and a granite (pl. 1).

\section{JEFFERS BLOCK(?)}

South of the Morton Block in South Dakota is what is tentatively identified as the Jeffers Block(?) (pl. 1), although it is not clear if this terrane is truly correlative to the Jeffers Block defined in Minnesota. The first basement rock intersected in many areas of the Jeffers Block(?) is 
the Sioux Quartzite (estimated age of 1,750 to 1,630 Ma; Holm and others, 1998; Czeck and Ormand, 2007; Medaris and others, 2007). Other rock types intersected during drilling are granite and diabase.

Moderate to high amplitudes of the horizontal magnetic and gravity gradients on the first horizontal derivative maps (figs. 4 and 5, respectively) are present along the margins of the Jeffers Block(?) in South Dakota. Distinctive linear features are apparent on the aspect map (fig. 6) along its margin with the Sioux Block. These geophysical characteristics do not appear to be characteristic of the Jeffers Block in Minnesota, indicating that the Jeffers Block(?) in South Dakota has been strongly deformed along its margin with the Sioux Block or it's not equivalent to the Jeffers Block in Minnesota. Another possibility is that the different characteristics are an effect of the vastly different resolution in the aeromagnetic data between the two states.

The southern margin of the Jeffers Block(?) lies within a zone of volcanic rocks (rhyolite and possible latite) intersected in drill holes. This zone has a fairly distinctive aeromagnetic signature (fig. 2), consisting mainly of small areas of alternating magnetic highs and lows forming a beadlike string. These volcanic rocks may be responsible for the unusual pattern on the aspect map (fig. 6), perhaps indicating cooling across a polarity switch of the Earth's magnetic pole.

\section{SIOUX BLOCK}

South of the Jeffers Block(?) and western extent of the Montevideo Block in South Dakota lies the Sioux Block (defined and named herein; pl. 1). By far the most common rock type intersected within this block is the Sioux Quartzite. Granite and diabase (at least some of which is the Corson diabase) have also been intersected during drilling. Both the Sioux Quartzite and the Corson diabase occur in outcrop, although the outcrop extent in this area is extremely limited. The Corson diabase intruded the Sioux Quartzite as sills within the Sioux Block (Sklar, 1982). The age of the Corson diabase is unknown and limited work has focused on these intrusives. In an M.S. thesis that focused on Precambrian mafic intrusives in eastern South Dakota, the author speculated that the Corson diabase is related to the Mid-continent Rift System (Sklar, 1982). This interpretation is questionable as these sills do not appear to be widespread in the region.

The Sioux Block is characterized by curvilinear to circular features in the geophysical data (figs. 2 through 6), and appears to be rimmed from the west to east around its southern margin by positive magnetic and gravity anomalies (figs. 2 and 3). The distinctiveness of this terrane is particularly evident in the aspect map (fig. 6), which shows broad, curved areas of relatively constant azimuth of the maximum aeromagnetic gradient.

Granitoid intrusions of ca 2,600 Ma are interpreted to have been sutured to the southern part of the Superior Craton (Chandler and others, 2007), specifically, the Jeffers Block in Minnesota (Southwick and others, 1994). The Sioux Quartzite covers much of the older basement, making an accurate assessment of the range of rock types occurring in the Sioux Block impossible at this time. Granites do occur in drill holes from this block, but have not been dated. Volcanic rocks occur along the northern margin of the Sioux Block. Two latitic or andesitic rocks and two 
rhyolites were intersected within the Sioux Block near its northern margin, and one rhyolite was intersected within the southwestern corner of the Montevideo Block just north of the Sioux Block margin. One microgranite was intersected within the Jeffers Block(?) just north of the Sioux Block margin, as well. Radiometric dates for two of the volcanic rocks ( $\mathrm{Rb}-\mathrm{Sr}$ whole rock age for the altered rhyolite in the Montevideo Block and $\mathrm{Rb}-\mathrm{Sr}$ whole rock age for the quartz latite rock in the Sioux Block) are 1,698 Ma, and should be considered minimum ages (table 1). The U-Pb zircon age for one rhyolite in the Sioux Block is $1,828 \pm 8 \mathrm{Ma}$ and the $\mathrm{U}-\mathrm{Pb}$ zircon age for the microgranite in the Jeffers Block(?) is 1,790 \pm 13 Ma (table 1, Van Schmus and others, 2007; see DISCUSSION section for more detail). Samarium-neodymium model ages of the microgranite north of the Sioux Block and the meta-rhyolite within this block are 2,570 and 2,590 Ma, respectively (table 1, Van Schmus and others, 2007), which is consistent with the age of these syn- to late-tectonic granitoid intrusions.

Gabbro was intersected in two drill holes in northwestern Clay County (within 2 miles of each other), north of the boundary with the Superior Boundary Zone (pl. 1). The two holes were drilled for WMC Exploration Incorporated in 2003 and each intersected over 1,000 feet of gabbro. Three additional drill holes intersected gabbro in the Superior Boundary Zone just south of the Sioux Block in southern Yankton and north and central Union Counties.

The Sioux Quartzite, the dominant Precambrian formation of the Sioux Block, is part of the Baraboo interval, which includes the Baraboo, McCaslin, Flambeau, Barron, and Sioux Quartzites (Czeck and Ormand, 2007). The present literature suggests the basins into which the Baraboo and similar quartzites that span from Arizona to Wisconsin and possibly into Canada are related to the Mazatzal Orogeny to the south. The more recent models include deposition into syntectonic extensional back-arc basins of highly weathered first generation sediments (Jones and others, 2009), and deposition into fore-arc basins of multi-cycle clastics (Carlson, 2007) or foreland basins on a stable cratonic margin with subdued topography (Czeck and Ormand, 2007). The tectonic setting model favored here for the Sioux Quartzite, which shows little deformation or thermal overprinting, and which overlies mainly Trans-Hudson terrane and the Superior Craton, is that of a foreland basin lying north of the main Mazatzal deformation front (Craddock and McKiernan, 2007; Czeck and Ormand, 2007). For further discussion, see "Timing of deposition of the Sioux Quartzite" under the DISCUSSION heading.

\section{Pikwitonei-like Terrane}

Also included in the Superior Craton in South Dakota is a Pikwitonei-like Terrane, sandwiched between the Superior Boundary Zone on the west and parts of the Wawa and Minnesota River Valley Subprovinces to the east (pl. 1). On the Canadian Shield, the Pikwitonei is a terrane adjacent to and east of the Churchill-Superior Boundary Zone characterized by granulite-grade gneiss having strong positive gravity and magnetic anomalies (Lewry and others, 1990; White and others, 2005). It is interpreted to represent an uplifted slice of lower Archean crust (Green and others, 1979; Lewry and Collerson, 1990). The Pikwitonei-like Terrane in South Dakota is in a similar position relative to the boundary zone as the Pikwitonei in Canada and is also characterized mainly by high gravity and magnetic values, similarities that have been noted by previous workers (Klasner and King, 1986). However, the few samples of this terrane 
(granite, gneiss, and greenstone) suggest a lower metamorphic grade than that observed on the Canadian Shield (Klasner and King, 1986; this study). This Pikwitonei-like Terrane may also represent an uplifted block of the Superior Craton, but perhaps not from as deep of a section of the crust as the type Pikwitonei Terrane.

The pronounced, northeast-striking fabric of the Superior Craton, as observed in the aeromagnetic and gravity data, is abruptly truncated at the northeastern margin of the Pikwitoneilike Terrane (figs. 2 and 3). Two large northeast-southwest trending faults are also mapped in the Pikwitonei-like Terrane. The southern of these two faults may be a continuation of the Great Lakes Tectonic Zone as mentioned in the previous section.

Rock types intersected in drill holes within the Pikwitonei-like Terrane include granite, gneiss, and greenstone, as mentioned previously. Granite cuttings from southwestern Walworth County yield an Rb-Sr biotite age of 1,750 Ma (table 1, Goldich and others, 1966; Sims and others, 1991), a biotite-garnet gneiss from Jerauld County yields an Sm-Nd whole rock age of 2,830 Ma, with an Sm-Nd biotite-garnet age of 2,490 Ma, and a biotite gneiss from northwestern Sanborn County yields an Sm-Nd whole rock age of 2,720 Ma (table 1, Sims and others, 1991; Hull and others, 2009).

\section{Superior Boundary Zone}

The Superior Boundary Zone mapped in South Dakota (Lidiak, 1971; Klasner and King, 1986, 1990; Sims and others, 1991; this study) is considered the extension of the ChurchillSuperior Boundary Zone defined on the Canadian Shield. It consists of Archean Superior Craton and Proterozoic rocks that have undergone significant deformation during suturing of the Wyoming and Superior Cratons. North-south to northwest-southeast trending features (shears/faults) and northeast-southwest trending faults typify this terrane (pl. 1). Some of the northeast-southwest trending faults are known to be normal faults (Steece, 1962; Nichols and others, 1989; Sims and others, 1991).

The Superior Boundary Zone has a very distinct aeromagnetic fabric and character as compared to the adjacent terranes (figs. 2 and 3). The Superior Boundary Zone in South Dakota generally has a lower magnetic signature, although in its southeastern portion, several magnetic highs are present. Similar areas of magnetic highs and lows are also observed in the Canadian Churchill-Superior Boundary Zone. In South Dakota, much of the eastern margin of the Superior Boundary Zone is a magnetically low region, characteristic of many regions of the ChurchillSuperior Boundary Zone in Canada (White and others, 2005). The western margin of this terrane for much of its extent in South Dakota is defined by very steep gravity gradients (fig. 5).

Rock types within the Superior Boundary Zone are varied in South Dakota. Drill holes have intersected schists, granite, gneiss, diorite, granodiorite, gabbro (along the southern margin of the Sioux Block), and Sioux Quartzite. Radiometric dates are variable in quality and range of measured ages, but are generally consistent with a zone of significantly reworked Superior Craton margin and Proterozoic rocks. The three published radiometric dates are all from granitic rocks (table 1). A quartz monzonite cuttings sample from a northern Stanley County drill hole 
yielded an Rb-Sr feldspar age of 1,660 Ma (Goldich and others, 1966; Sims and others, 1991), a granite or gneiss cuttings sample from a northernmost Aurora County drill hole yielded an $\mathrm{Rb}-\mathrm{Sr}$ whole rock date of 1,930 Ma (Sims and others, 1991), and a granodiorite core sample from a central Davison County drill hole yielded a U-Pb zircon age of 1,871 \pm 16 Ma with an Sm-Nd model age of 2,550 Ma (Van Schmus and others, 2007).

Interpretations resulting from this study indicate that the Superior Boundary Zone wraps around the southern margin of the Superior Craton in South Dakota. Within this southern extent, in addition to the Sioux Quartzite, are a granodiorite intersect, several gabbro intersects, and one possible iron formation intersect. The cuttings of the possible iron formation are poor in quality, consisting of finely ground rock. The geophysical character of this southern zone is distinct in that positive magnetic and gravity anomalies encompass most of the area. Gradient maxima on the magnetic and gravity derivative maps (figs. 4 and 5) also characterize the area, suggesting a fairly unique region dominated by dense, magnetic rock underlying the Sioux Quartzite.

Within the Iowa section of the Superior Boundary Zone as interpreted in this study, several cores were drilled in 1963 in Lyon and Sioux Counties (fig. 7) in and around a positive aeromagnetic anomaly (Tvrdik, 1983). This drilling was part of the Matlock project carried out by the New Jersey Zinc Company. Drill holes intersected several rock types indicating that this feature is a layered intrusion (Yaghubpur, 1979; Tvrdik, 1983; Windom and others, 1993).

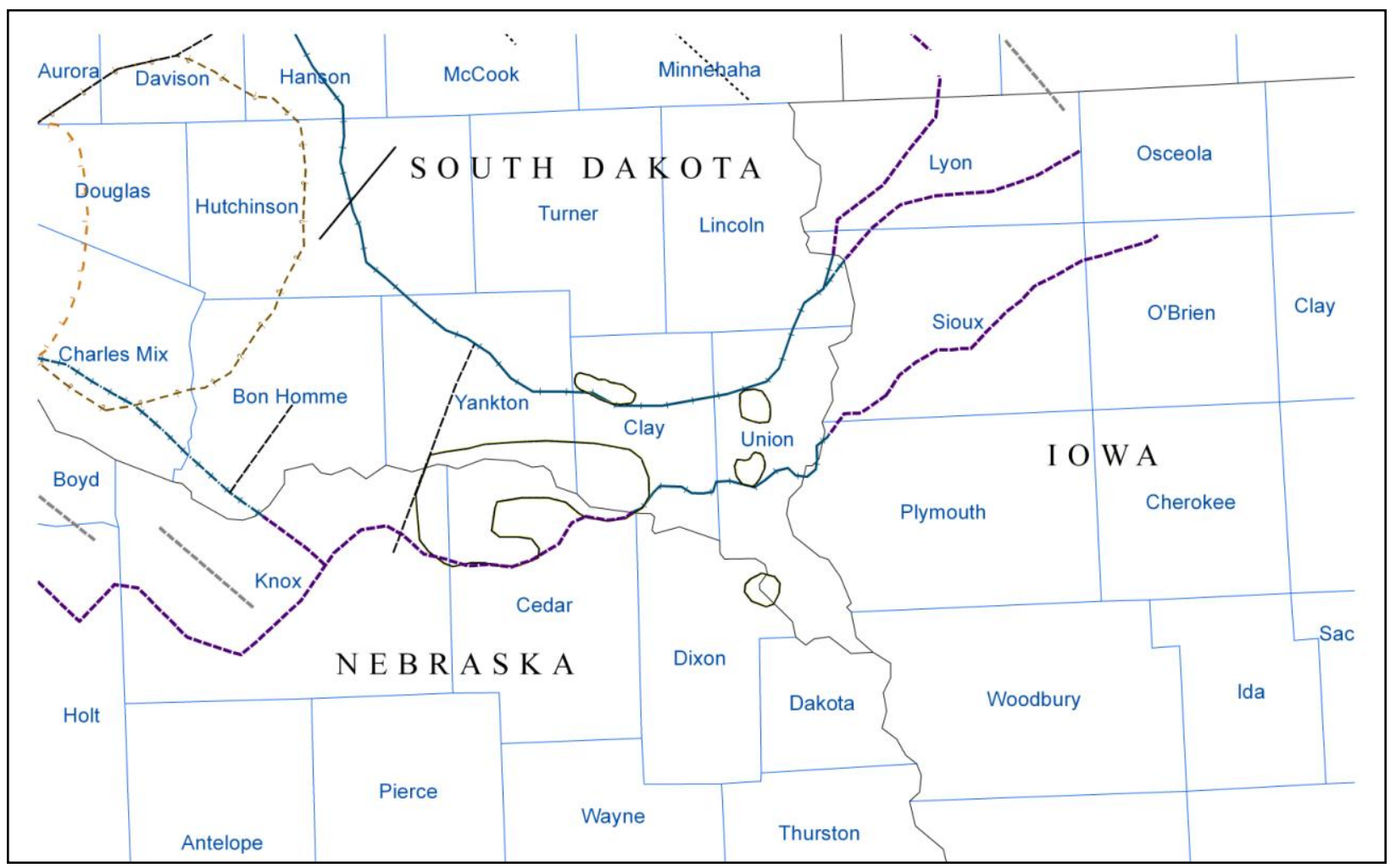

See plate 1 for explanation of lines showing basement structures, faults, and structural boundaries

Figure 7. Map showing state boundaries and names, and county boundaries and names for southeast South Dakota, northeast Nebraska, and northwest Iowa. 
The complex was named the Otter Creek layered igneous complex by Windom and others (1993). On the aeromagnetic map, positive magnetic anomalies of similar size and magnitude occur to the northeast and southwest of the Otter Creek layered complex. This trend clearly extends through northern Union County in South Dakota (Windom and others, 1993; this study).

The rocks of the Otter Creek layered complex have undergone extensive alteration in most cases, but apparently have not experienced significant deformation, and the original mineralogy and primary rock types can still be distinguished (Tvrdik, 1983). Rock types within the layered intrusion included anorthosite, gabbronorite, pyroxenite, and peridotite (Tvrdik, 1983). The intrusion is overlain in its southern extent by iron formation, which has been contact metamorphosed by the intrusion (Yaghubpur, 1979; Tvrdik, 1983).

Published dates for some of these rocks include a 2,523 $\pm 5 \mathrm{Ma}$ U-Pb zircon age for a quartz monzodiorite intersected in one of the Matlock cores (Tvrdik, 1983; Windom and others, 1993), and an Sm-Nd model age for the Otter Creek layered complex of 2,890 $\pm 90 \mathrm{Ma}$ (Windom and others, 1993). The Otter Creek complex is overlain by felsic pyroclastic rocks that yield a U-Pb age of 1,782 $\pm 10 \mathrm{Ma}$ (Windom and others, 1993).

\section{$\underline{\text { Wyoming Craton }}$}

Like the Superior Craton discussed above, the Wyoming Craton proper encompasses that part of the craton that is believed to have undergone little or no modification by collision with the Superior Craton to the east or by the accretion of island arcs during the Yavapai Orogeny to the south. The Wyoming Craton outlined here is similar to various published maps (Klasner and King, 1986; Sims and others, 1991). In this study, the eastern border of the Wyoming Craton proper is the northern extension of the Hartville Fault of Sims and others (2001). This fault is a distinctive feature on the derivative gravity map (fig. 5). The amplitude of this gravity gradient dies out in northwestern Lawrence County, but the eastern border of the Wyoming Craton is inferred to continue northwest following a more moderate gradient amplitude on the first horizontal derivative gravity map.

\section{Wyoming Boundary Zone}

It was suggested by Gosselin and others (1988) that the Black Hills is in a position similar to the Cree Lake Zone in Saskatchewan. In Canada, the Cree Lake Zone is a broad mobile belt consisting of multiple domains of Archean basement overlain by supracrustal rocks along the western craton margins (Green and others, 1985). Lewry and Collerson (1990) also imply that the Cree Lake Zone correlates with the Black Hills on their figure 1. They go further by calling the Black Hills part of the Wyoming Boundary Zone and extending this boundary zone southward, wrapping it around the eastern and southern margins of the Wyoming Craton.

The interpretation of the Wyoming Boundary Zone in this study is consistent with those of Gosselin and others (1988) and Lewry and Collerson (1990). The Wyoming Boundary Zone 
mapped here consists of Archean basement terrane and supracrustal material that has been deformed by collision to the south with the Yavapai Terrane and to the east with the southern Trans-Hudson Orogen. In some previous work, this boundary zone has been included with the Wyoming Craton proper (Green and others, 1985; Nelson and others, 1993) because it contains Archean rocks of Wyoming Craton chemical affinity. Examples of such Archean rocks are the Little Elk Granite and associated Archean metasediments, which crop out on the eastern margin of the exposed Precambrian rocks of the Black Hills (Walker and others, 1986; Gosselin and others, 1988; McCombs and others, 2004; Redden and DeWitt, 2008). Wyoming cratonic rocks are certainly part of the Black Hills and may, in fact, completely underlay this region (Houston, 1993; J. Redden, oral commun., 2009). However, significant thermotectonic overprinting in the Black Hills is well documented over the period of ca 1,780 to 1,690 Ma (Dahl and others, 2005) throughout the exposed basement, justifying the exclusion of the Black Hills from the Wyoming Craton proper. The interior (western) margin of the Wyoming Boundary Zone is the Hartville Fault, which extends from the Hartville Uplift in Wyoming to the northern Black Hills. A similar boundary was proposed by Sims and others (1991).

It is suggested here that the Wyoming Boundary Zone in and around western South Dakota can be subdivided into the following domains (pl. 1). These domains, from north to south, are the Cedar Creek Domain (new name), the Black Hills Domain, and the Hartville Domain (new name).

\section{CEDAR CREEK DOMAIN}

The Cedar Creek Domain is bound on its eastern side by the Cedar Creek Fault, a major structural feature that trends southeast from Montana through much of South Dakota. This domain encompasses the northern part of the North American Central Plains anomaly [see figures in Jones and Savage (1986) and Klasner and King (1986)]. In Montana, this domain is included in the Wyoming Craton proper and mapped as Archean granites and gneisses (Sims and others, 2004).

In South Dakota, the Cedar Creek Domain is characterized by moderate to low gravity and magnetic signatures. On the derivative magnetic maps (figs. 4 and 5), this domain displays long, linear features that are parallel to the Wyoming Craton margin and the Cedar Creek Fault. The linear features probably represent faults and perhaps thrust sheets. Precambrian drill-hole intersects in this domain are restricted to granite and felsic gneiss. One gneiss core yielded an $\mathrm{Rb}-\mathrm{Sr}$ whole rock date of 1,729 Ma, with an Sm-Nd model age of 3,050 Ma (table 1, Goldich, and others, 1966; Sims and others, 1991).

\section{BLACK HILLS DOMAIN}

The Black Hills Domain displays north-south and strong northwest-southeast structural trends. These trends are represented on the derivative maps as subtle north-south and abrupt northwest-southeast striking zones beyond which gradient amplitude decreases (figs. 4 and 5). 
The Black Hills Domain includes the Precambrian outcrop of the Black Hills. The Black Hills were uplifted during the Laramide Orogeny (perhaps starting as early as $64 \mathrm{Ma}$ in this region; Lisenbee, 2010). This recent uplift may have reactivated at least some Precambrian structures (Lisenbee, 2010).

The Black Hills Domain also includes the North American Central Plains anomaly [see figures in Jones and Savage (1986) and Klasner and King (1986)]. The domain is characterized by moderate relief on the complete Bouguer anomaly map (fig. 3). At the resolution of the aeromagnetic data used here (Kucks and Hill, 2002), the Black Hills Domain has only moderate magnetic relief except along its northeastern margin, where the relief increases noticeably (fig. 2). Based on the aeromagnetic map, an argument could be made to include the northeastern portion of the Black Hills Domain with the Cedar Creek Domain. The decision to keep this portion within the Black Hills Domain is based on the strong decrease in the gradient amplitude on the first horizontal derivative gravity map (fig. 5).

The northern boundary of this domain is defined by very distinctive changes mainly in the gravity and derivative gravity maps (figs. 3 and 5), beginning with the sharply decreasing amplitude of the gravity gradient, representing the termination of the Hartville Fault. The northern/northeastern border of the Black Hills Domain is placed just to the northeast of steep, almost horseshoe-shaped gradients on the derivative gravity map (fig. 5), and is mapped as a fault. The eastern and southeastern margins of the Black Hills Domain are characterized by moderate to subtle changes in magnetic fabric, and gravity and magnetic intensity. The placement of the boundary is approximate along the southeastern margin where the geophysical relief is low. In this region, the boundary is defined to a great extent by the elevation contour map of the Precambrian surface (McCormick, 2010).

Numerous radiometric dates have been obtained from Precambrian rocks within the outcrop area of the Black Hills Domain. The dates range from Archean through Proterozoic (Redden and others, 1990; McCombs and others, 2004; Chasten, 2009; Dahl, 2010). In outcrop, rock types span a large range from schists to granite to banded iron formation and are too numerous to list. In the subsurface, rock types intersected in drill holes are schist, granite, and quartzite. One radiometric date from a granite cuttings sample has been published (table 1). The Rb-Sr biotite date is 1,490 Ma (Goldich and others, 1966; Sims and others, 1991).

\section{HARTVILLE DOMAIN (WYOMING)}

The Hartville Domain contains rocks of the Hartville Uplift, and has distinctive northeastsouthwest trending features, apparent in the derivative magnetic data. This domain is only partially mapped here, due to the focus of this work on South Dakota terranes. However, it is likely that this domain terminates against the Laramie Mountains. Its boundary with the Yavapai Terrane is defined by the outer margin of the Cheyenne Belt.

Previous work has placed much of this proposed domain within the North American Central Plains anomaly (Jones and Savage, 1986; Klasner and King, 1986; Houston, 1993). This entire domain (as mapped here) is included within a zone of the Wyoming Craton having been affected 
by 1,800 Ma and younger events and containing Proterozoic rocks deposited on the Archean craton (Jones and Savage, 1986; Houston, 1993). In fact, Houston (1993) defines a boundary zone (based heavily on thermal overprinting) much larger than is proposed here, penetrating much deeper into Wyoming. The interior (western) margin of the Wyoming Boundary Zone presented in this study is mainly defined on geophysical data, in this case the high amplitude gravity gradient corresponding to the Hartville Fault, as mentioned previously.

\section{$\underline{\text { Yavapai Terrane }}$}

The Yavapai Terrane (pl. 1) is part of what was originally termed the Central Plains Orogen (Sims, 1985; Sims and Peterman, 1986). Sims and Peterman (1986) noted that the Central Plains Orogen consisted of a northern (ca 1,700 Ma) terrane and a younger terrane, and further, noted the apparent absence of Archean-aged rocks within the Central Plains Orogen. The 1,700-1,800 Ma terrane is now referred to as the Yavapai Orogen (Van Schmus and others, 1993; Holm and others, 2007), with the younger terrane of Sims and Peterman (1986), a 1,600-1,700 Ma terrane, generally referred to as the Mazatzal Orogen. Sims and Peterman (1986) also noted the northwest-trending fabric of the magnetic and gravity anomalies in the northern Central Plains terrane.

In northeastern Nebraska, southeastern South Dakota, northwestern Iowa, and southern Minnesota, the northern margin of the Yavapai Orogen is defined by the Spirit Lake Tectonic Zone (Van Schmus and others, 2007). The zone is represented by a discontinuity in the magnetic data, with the positive magnetic anomalies north of the boundary (figs. 2 and 4). The Spirit Lake Tectonic Zone cannot be distinguished west of eastern Knox County in Nebraska (figs. 2 and 7).

The westward extension of the northern boundary of the Yavapai Orogen is poorly constrained across most of southern South Dakota/northern Nebraska. The extension of this boundary must in some way couple with the Cheyenne Belt, which separates Paleoproterozoic and Archean rocks to the north from Proterozoic rocks with no Archean basement to the south in southeastern Wyoming (Houston, 1993). The western section of the Yavapai boundary that links with the Cheyenne Belt, as drawn here, parallels, but is somewhat northwest of Carlson's (2007) proposed boundary between the oldest Central Plains accretionary terrane, the 1,780 Ma Dawes Terrane, and the Wyoming Boundary Zone (as defined in this study).

Unlike the Yavapai margin in southeastern South Dakota, the boundary across southern South Dakota and northern Nebraska is distinguished by a considerably more discontinuous line of magnetic anomalies where generally more magnetic rocks are to the north and generally less magnetic rocks are to the south (figs. 2 and 4). On the first horizontal derivative of the gravity data, the Yavapai margin is generally distinguished by a high amplitude in the gravity gradient through northern Nebraska and southern South Dakota (fig. 5).

Three Precambrian samples from the Yavapai Terrane in South Dakota have been dated (table 1). An Rb-Sr feldspar date from granite cuttings from a drill hole in southern Union County is 1,460 Ma (Goldich and others, 1966; Sims and others, 1991). This drill hole is of particular interest because it penetrated 1,723 feet of Precambrian rock, according to the drilling 
records (Bolin and Petsch, 1954; Geological Survey Program, 2010). The lithologic log reports about 900 feet of granite with minor zones of schist, granodiorite, and hornfels. No lithology was reported from 1,914 to 1,932 feet. An apparent shear zone was intersected from about 1,932 to 2,140 feet. Lithologies reported in this interval include altered granite and possible mylonite. From 2,140 to 2,224 feet, the lithology is mainly hornfels, with minor pegmatite noted at the top and greenstone or chlorite schist noted at the bottom of the interval. No lithologies were reported from 2,224 to 2,752 (total depth).

Recent radiometric dates and Sm-Nd model ages obtained from cores in southeastern South Dakota yield a 1,762 $\pm 28 \mathrm{Ma}$ U-Pb zircon date and 2,080 Ma model age for a granite from southern Clay County, and a 1,733 $\pm 2 \mathrm{Ma} \mathrm{U}-\mathrm{Pb}$ zircon date and 2,170 Ma model age for a metagabbro from southern Union County (Van Schmus and others, 2007). These dates constrain the location of the Spirit Lake trend and northern boundary of the Yavapai Orogen in this area (Van Schmus and others, 2007).

\section{Internides of the Southern Trans-Hudson Orogen}

Numerous authors have extended several Trans-Hudson terranes, such as the Glennie Domain, the Flin Flon Belt, and the Kisseynew Domain of the Canadian Shield (fig. 8),

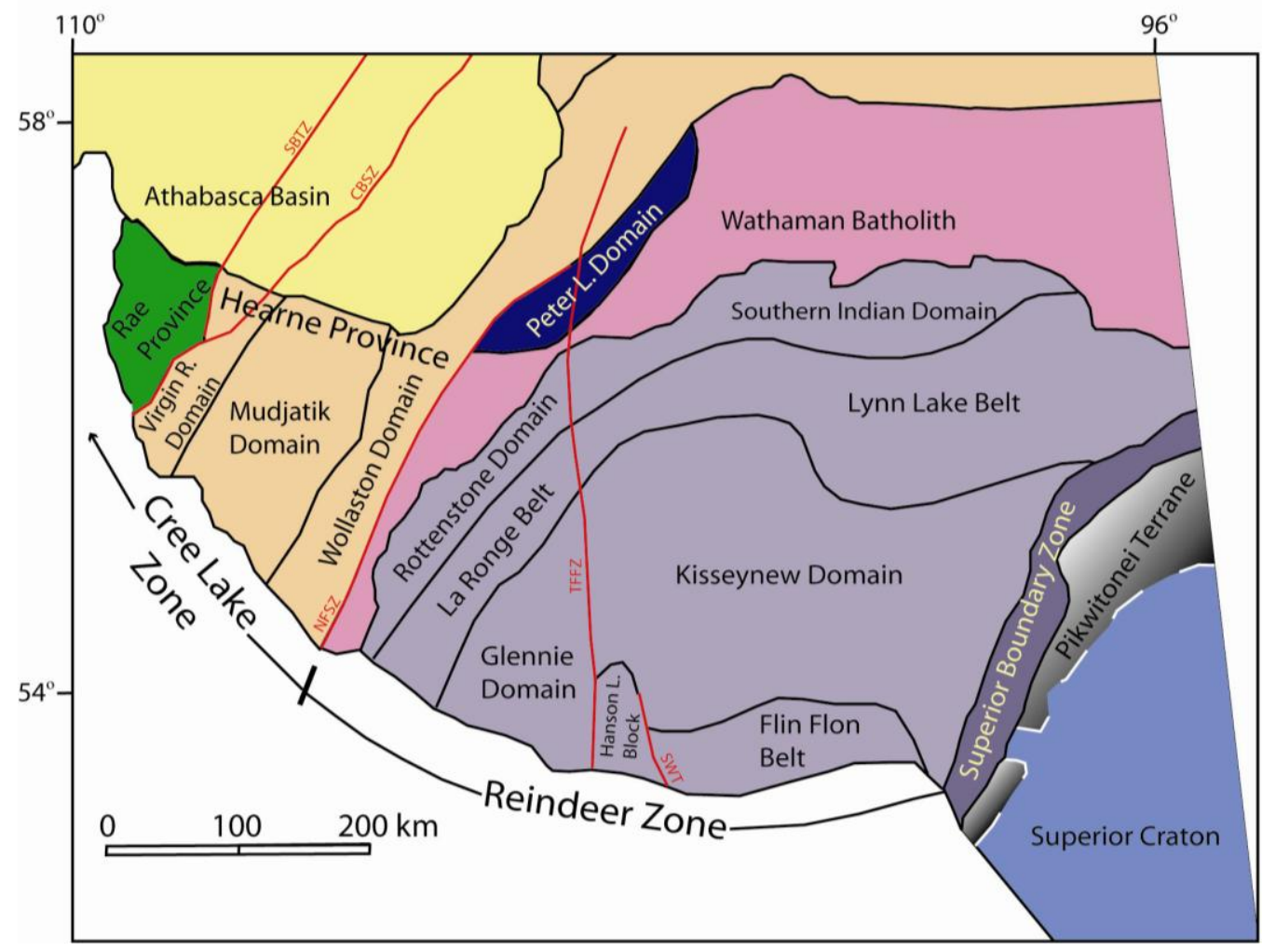

Modified from Annesley and others (2005) and White and others (2005)

SWT = Sturgeon-Weir Thrust

TFFZ = Tabbernor Fault and Fold Zone

NFSZ $=$ Needle Falls Shear Zone

CBSZ = Cable Bay Shear Zone

SBTZ = Snowbird Tectonic Zone

Figure 8. Simplified terrane map of the Trans-Hudson Orogen on the Canadian Shield, Saskatchewan and Manitoba, Canada. 
southward beneath the Paleozoic cover of southern Canada, into North Dakota, and southward through South Dakota to the terminus of the Trans-Hudson terrane against the Yavapai Orogen (Green and others, 1985; Klasner and King, 1986; Lewry and others, 1990; Nelson and others, 1993). Yet, South Dakota drill-hole data show a lack of rock-type equivalency with that of the Canadian Shield. Furthermore, it is unlikely that the metamorphic grades and level of erosion of these internides are similar to that observed on the Canadian Shield. In fact, Peterman and Goldich (1982) dated granulites within the Trans-Hudson Orogen from northern North Dakota. Their conclusion was that the basement to these granulites is Archean. Baird and others (1996) argued that because rock type, metamorphic grade, and level of erosion of the Proterozoic internides likely differ southward from the Canadian Shield, it is not appropriate to use the Trans-Hudson internide nomenclature in the southern extensions of the Trans-Hudson Orogen. Their point is well taken, but this nomenclature does convey certain spatial associations of the Trans-Hudson Orogen internides that are useful to retain southward. In this study, where geophysical continuity between Canadian internides and the internides of the Dakotas is observed, Canadian nomenclature is used, but with the modifier "southern" (pl. 1). There is some precedence in using the "southern" modifier. Holm (1999) used "southern" as a modifier in referring to the Trans-Hudson internides in South Dakota, though more to indicate the lack of full equivalency in timing of the closure than lack of full equivalency in the rocks themselves.

\section{Southern Flin Flon Belt}

On the Canadian Shield, the Flin Flon Belt (fig. 8) consists mainly of low-grade arc volcanic and plutonic rocks displaying an irregular pattern of magnetic highs and lows (White and others, 2005). Using White and others (2005) as a starting point, the inferred geophysical extension of the Flin Flon Belt was traced in this study from the Canada-United States border through North Dakota into South Dakota using aeromagnetic and gravity data. The most dominant geophysical feature of this terrane in South Dakota is the broad positive magnetic anomaly present in the northern half of the terrane just west of the Superior Boundary Zone that extends into North Dakota (fig. 2). It has been proposed that this feature represents Archean crust. One explanation for the presence of this large positive magnetic anomaly is that it is an exotic Archean crustal fragment (Klasner and King, 1986, 1990) termed the Dakota block (Baird and others, 1996). For an in-depth discussion of this idea, see the second subsection of the DISCUSSION.

South of this large positive magnetic anomaly, a more irregular pattern of smaller positive magnetic anomalies dot this terrane (fig. 2). On the first horizontal derivative magnetic map (fig. 4), this region south of the proposed Archean fragment appears as a fairly large magnetically quiet zone (fig. 4). The Southern Flin Flon Belt is terminated against the large gravity low in south-central South Dakota (fig. 3). The magnetically quiet zone extends into this area characterized by the gravity low.

Rock types intersected in drill holes in this terrane in South Dakota are restricted to granite and Sioux Quartzite. Metamorphic grade is not known. Rock-type calls are from cuttings, not core, and are typically based on a small quantity of, typically 3 millimeters diameter or less, rock and mineral chips. Radiometric dates from cuttings of two granite samples have been published (table 1). An Rb-Sr feldspar date, determined using cuttings from central Perkins County, is 
1,790 Ma and an $\mathrm{Rb}-\mathrm{Sr}$ feldspar date, determined using cuttings from southern Perkins County, is 1,810 Ma (Goldich and others, 1966; Sims and others, 1991).

\section{Southern Tabbernor Fault and Fold Zone}

On the Canadian Shield, the Tabbernor Fault and Fold Zone separates the Glennie Domain from the Flin Flon Belt. Lewry and others (1990) note the Tabbernor Fault and Fold Zone as a "feature of regional importance" that can be traced well into North Dakota. This zone is a major north-south striking feature, generally composed of lineaments, brittle faults, and plastic strain zones that, at least in Saskatchewan, locally coincide with a rapid increase in metamorphic grade (Wilcox, 1991). On the southernmost edge of the exposed Canadian Shield, this fault and fold zone separates the Glennie Domain on the west from the Hanson Lake Block to the east (fig. 8).

White and others (2005) describe the geophysical character of this fault zone as a southward widening area of subdued magnetic relief, extending it from the Canadian Shield to the United States border. In North Dakota this fault zone appears to be bounded on its western margin by a few discontinuous, elongated (at the resolution of the available aeromagnetic data) magnetic highs. The northernmost of these positive magnetic anomalies overlaps into Canada and resides just inside the margin of the Tabbernor Fault and Fold Zone as drawn by White and others (2005). The extension of the Tabbernor Fault and Fold Zone narrows southward.

The Southern Tabbernor Fault and Fold Zone appears to extend into South Dakota as a narrow belt (less than 10 miles wide) of moderately low magnetic intensity and low relief (magnetically quiet). It flares to more than 15 miles in width locally, but terminates in eastcentral Meade County (fig. 2). To the east, the boundary between the Southern Tabbernor Fault and Fold Zone and the Southern Flin Flon Belt is distinct due to the strong positive aeromagnetic signature of the northern part of the Southern Flin Flon Belt. To the west, the boundary between the Southern Tabbernor Fault and Fold Zone and the Southern Glennie Domain is more subtle.

\section{Southern Glennie Domain}

On the Canadian Shield, the Glennie Domain (fig. 8) consists mainly of quartz dioritic to granodioritic orthogneisses and plutons (White and others, 2005). On the exposed shield, this domain has a chaotic magnetic pattern similar to that of the Flin Flon Belt, but in the subsurface in Canada, the inferred extension of the Glennie Domain commonly displays strong, broad positive magnetic anomalies (White and others, 2005).

The inferred extension of the Glennie Domain south of the Canadian border is characterized by low magnetic relief of moderate to moderately low intensity. This characteristic is similar to that of the narrow south-trending arm of the Glennie Domain in Canada as it intersects the United States border (White and others, 2005). Through North Dakota, the extension of the Glennie Domain maintains a fairly constant width, but is reduced to a width of less than 15 miles at the North Dakota-South Dakota border. In South Dakota, the Southern Glennie Domain has low relief and moderately low to low magnetic intensity (fig. 2). 
In South Dakota, the western edge of the Southern Glennie Domain separates the low magnetic intensity and relief of this domain from the increased magnetic intensity and high magnetic relief of the Williston Domain. Together, the Southern Glennie Domain and Southern Tabbernor Fault and Fold Zone define a magnetically quiet zone separating the Southern Flin Flon Belt and the Williston Domain through much of South Dakota (fig. 4).

The placement of the Southern Glennie Domain-Southern Tabbernor Fault and Fold Zone boundary in South Dakota was finalized using an aspect map of the first horizontal derivative of the magnetic data. The aspect, as defined previously, is an azimuth direction of the maximum rate of change in value (in this case, slope) from each cell of a grid to its neighbors. By colorcoding the azimuth directions on this aspect map, one can observe textural variations between terranes. Noteworthy is the change in texture on the aspect map between the Southern Glennie Domain, which has widely varying azimuths with a dominant range of $0^{\circ}$ to $120^{\circ}$, and the Southern Tabbernor Fault and Fold Zone, which has both a much smaller variability of azimuth directions and a tighter cluster of azimuths ranging from $200^{\circ}$ to $280^{\circ}$. This feature of the Southern Tabbernor Fault and Fold Zone appears on the aspect map as a distinctively flat zone.

Only one drill hole within the Southern Glennie Domain and Southern Tabbernor Fault and Fold Zone intersected the Precambrian surface. This drill hole is located in northeastern Meade County near the southern end of the Southern Glennie Domain and intersected a granite or granodiorite (based on descriptions of cuttings).

\section{Williston Domain}

The Williston Domain (defined here; pl. 1) has considerable magnetic relief. This domain extends from northern margin of the Southern Dakota Terrane (defined below) into North Dakota and Montana. This domain is terminated on the north by the Assiniboia Terrane of White and others (2005). The Assiniboia Terrane is not exposed on the Canadian Shield.

In South Dakota, the western edge of the Williston Domain is the Cedar Creek Fault (Sims and others, 1991), a dominant structural feature that extends well into Montana. The eastern edge of this domain is defined by the magnetic low of the Southern Glennie Domain in the north and by the Southern Flin Flon Belt in the south. The Williston Domain-Southern Flin Flon Belt boundary is likely a fault. As compared to the Southern Flin Flon Belt, the Williston Domain has a much more variable pattern of magnetic highs and lows (fig. 2) and does not have the magnetically quiet areas that the Southern Flin Flon Belt has on the magnetic horizontal derivative map (fig. 4).

The southern boundary of the Williston Domain is defined by the greater density of high amplitude gradients on the derivative maps (figs. 4 and 5). This southern boundary is approximate in location and will need to be modified in the future.

Only three drill holes are known to have intersected Precambrian rocks in the Williston Domain. The rock types intersected are metasedimentary, metamorphic of unknown, but possibly sedimentary protolith, and granite/felsic gneiss. The two possible metasedimentary intersects are 
along and just to the east of the Cedar Creek Fault. As these two drill holes are oil tests and intentionally drilled along the fault, they do not represent a random sampling of rock types in this domain. Nonetheless, they do suggest some preservation of sediments within the otherwise granitoid-dominated terranes of the southern Trans-Hudson Orogen.

\section{Southern Dakota Terrane}

The Southern Dakota Terrane (newly designated and defined herein) is characterized by a central portion that has low magnetic relief of moderate intensity and a west and east portion that have strong positive magnetic anomalies (fig. 2). The western portion has a magnetic signature similar to the Williston Domain, but with a more variable orientation of the anomalies. The eastern portion is represented by (apparently) one large positive magnetic anomaly (this may be a function of the resolution of the data) and appears to suggest the event, such as intrusion, that produced this anomaly significantly deforms and thus post-dates the development of the Superior Boundary Zone.

The central portion of this domain is widely known in the literature for its low gravity anomaly (fig. 3), a feature noted by previous workers (Lidiak, 1971; Klasner and King, 1986; Sims and others, 1991). However, the number of gradient maxima in this region on the derivative gravity map (fig. 5) suggests some variability in rock densities within this domain. It has been suggested by Klasner and King (1986), Sims and others (1991), and others that this negative gravity anomaly is due to the presence of a large granitic batholith. In a later paper, Klasner and King (1990) simply refer to this region as part of an accreted magmatic arc. McGinnis and others (1979) commented that this gravity anomaly is a long wavelength feature (suggesting its source is deep) and may be caused by mass deficiencies in the mantle. In contrast to the gravity derivative map, the aeromagnetic derivative map shows a distinctively quiet region in this central portion of the Southern Dakota Terrane (fig. 4).

Rock types intersected in drill holes in this terrane are generally of similar compositions (granitic/felsic gneiss, possible rhyolite) to many other areas in the basement of South Dakota, but are not inconsistent with a batholith interpretation. One drill hole (in southeastern Lyman County) did intersect a possible metasedimentary rock. Cuttings are fair to poor in quality so the identification is tentative. This sample has been described as schist in the literature (Sims and others, 1991).

The interpretation here of the Southern Dakota Terrane is that it is mainly a magmatic terrane. The gravity low is attributed to a series of magmatic centers that may have produced some volcanism. The large positive magnetic anomaly at the eastern side of this domain is interpreted to be a large intrusion. The gravity values in this area are still fairly low, suggesting that the intrusion is granitic. The smaller positive magnetic anomalies on the west side of this domain may in part represent small intrusions, but only one (which has geophysical similarities to the eastern positive magnetic anomaly) is mapped as such in this study. The geometry of the gravity low relative to the margin of the Yavapai Terrane suggests that the development of the Southern Dakota Terrane is associated in some way with the Yavapai Orogeny. 
Three radiometric dates have been published for rocks within the Southern Dakota Terrane (table 1). An Rb-Sr feldspar date of 1,480 Ma is from quartz monzonite cuttings from a drill hole on the southern border of Tripp County, a 1,510 $\mathrm{Ma} \mathrm{Rb-Sr}$ feldspar date is from quartz monzonite cuttings from a hole drilled in southeastern Tripp County (Goldich and others, 1966; Sims and others, 1991) and a 1,550 Ma Rb-Sr whole rock date is from granite or rhyolite cuttings from a hole drilled in northern Gregory County (Sims and others, 1991). The granite or rhyolite cuttings sample also yielded a discordant $\mathrm{Pb}-\mathrm{Pb}$ date of 1,780-1,790 Ma (Sims and others, 1991).

Another feature of this domain is that it encompasses high geothermal gradients along its eastern margin. This pattern of geothermal gradient anomalies trends from southern Bon Homme County through northern Tripp County. Gradients reach $7^{\circ} \mathrm{F} / 100 \mathrm{ft}$, locally (Schoon and McGregor, 1974; this study). It seems likely that the main controls on the location of the northwest-southeast series of anomalies are the volcanic centers and associated magmatism in the Southern Dakota Terrane and structures related to the Superior Boundary Zone.

\section{DISCUSSION}

\section{Timing of the Southern Trans-Hudson Orogeny in South Dakota}

The terrane of the southern Trans-Hudson Orogen lies between the Wyoming and Superior Boundary Zones and north of the Yavapai Terrane (pl. 1). Radiometric dates of igneous activity and deformation events suggest final closure (on the Wyoming Craton side) occurred measurably later in South Dakota (ca 1,755 Ma) than to the north (1,800-1,900 Ma) (Dahl and Frei, 1998; Holm, 1999; Dahl and others, 2005). This late closure has prompted some workers to suggest "Black Hills Orogeny" as a more appropriate term than "Trans-Hudson" for this final closure (Goldich and others, 1966; Dahl and Frei, 1998). Black Hills Domain (Sims and others, 1991) has been suggested for the younger(?) (western) terrane of the southern Trans-Hudson Orogeny, encompassing an area considerably greater in extent than does the Black Hills Domain defined here. As mentioned previously, Holm (1999) prefers to maintain the Trans-Hudson term, but modify it to "southern Trans-Hudson Orogeny" to indicate the lack of full equivalency in timing of the closure.

Published radiometric dates from samples of the terrane between the Wyoming and Superior Cratons in South Dakota are few in number and variable in quality. Two samples from oil tests drilled in Perkins County (in the terrane identified as the Southern Flin Flon Belt in this study) fall around 1,800 $\mathrm{Ma}$ (table 1). These are $\mathrm{Rb}-\mathrm{Sr}$ feldspar ages (1,790 and 1,810 Ma, respectively; Goldich and others, 1966; Sims and others, 1991). They should be considered minimum ages of the rocks sampled and mainly reflect the most recent deformation event(s). These ages are close to the Trans-Hudson deformation age range (1,800-1,900 Ma) and are measurably older than the deformation associated with the southern Trans-Hudson Orogeny reported for the Black Hills (at around 1,755-1,750 Ma, Dahl and others, 2005). A date from a gneiss directly west of the Cedar Creek Fault on the eastern side of the Cedar Creek Domain (southeastern Butte County) gives an $\mathrm{Rb}-\mathrm{Sr}$ whole rock age of 1,729 Ma with an Sm-Nd model age of 3,050 Ma (Goldich and others, 1966; Sims and others, 1991). If these dates accurately represent the metamorphic overprint of final closure, a separate term for this late orogenic event may be warranted. Figure 9 presents a 
schematic of one possible conceptual model illustrating the timing of closure of the WyomingSuperior suture relative to the Yavapai Orogeny in South Dakota.
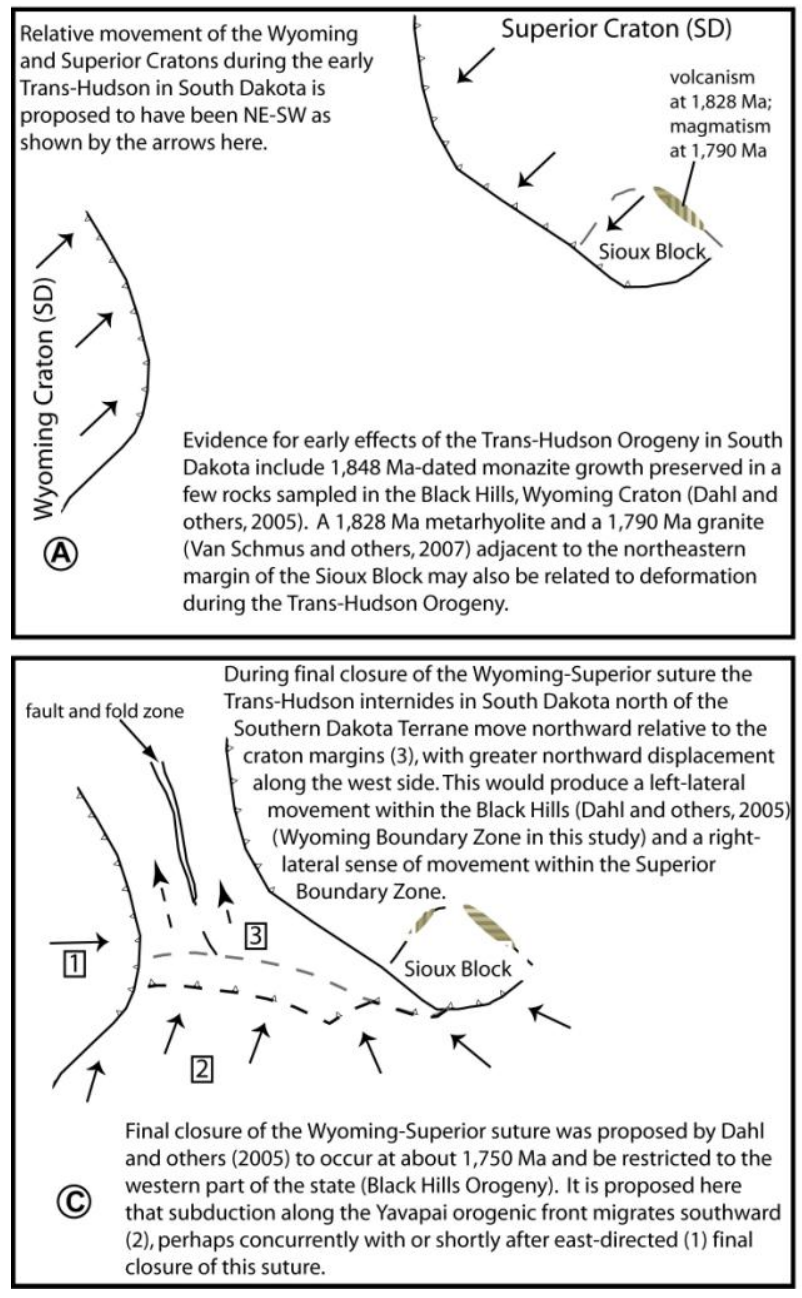

WBZ = Wyoming Boundary Zone
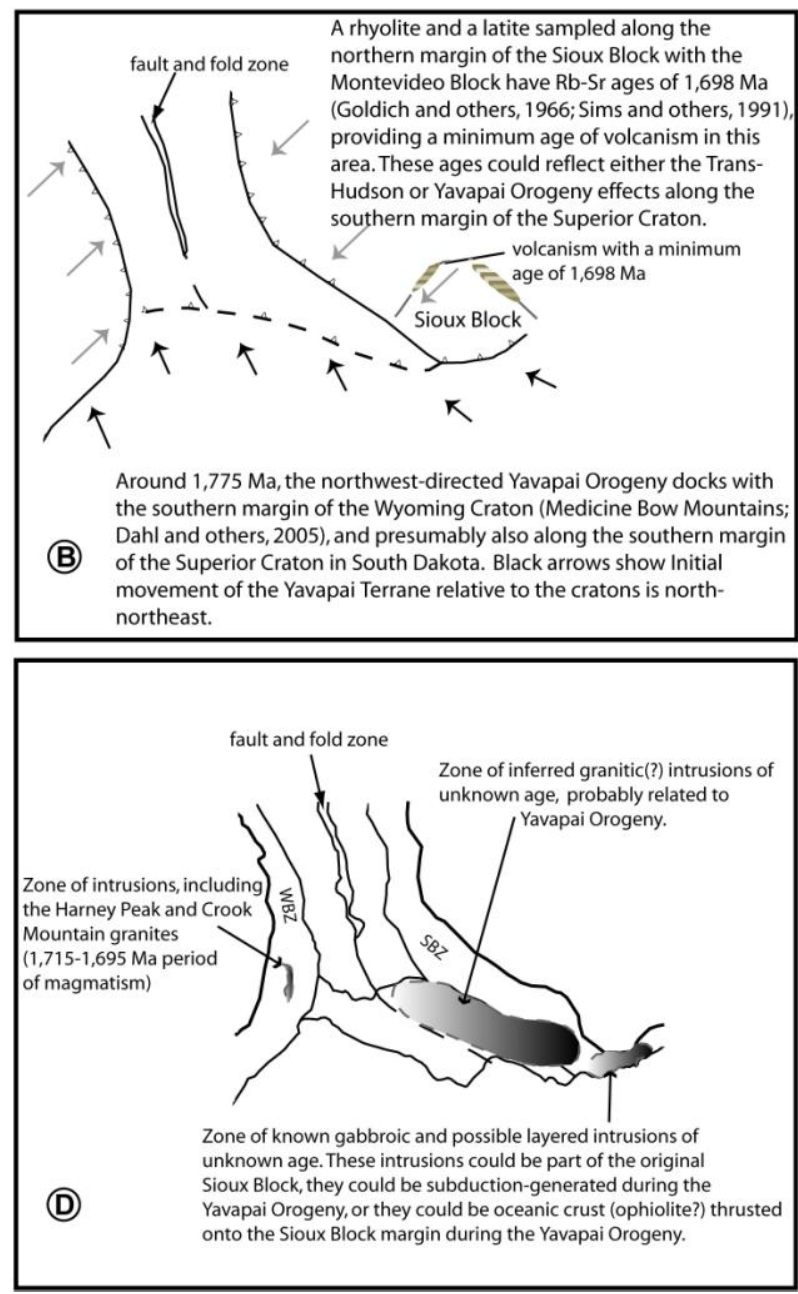

SBZ = Superior Boundary Zone

\section{Figure 9. A schematic of the Wyoming-Superior closure and Yavapai orogenic event starting with subduction under the Wyoming and Superior Cratons as the two cratons move toward each other (A) through closure of the Wyoming-Superior suture and subsequent collision of the Yavapai Orogeny (B, C), and ending with post orogenic intrusions (D).}

The possibility that the Wyoming-Superior collision was two discrete orogenic events in South Dakota (Trans-Hudson and Black Hills Orogenies) has significant implications for the interpretation of the southern terminus of the Trans-Hudson terrane. The most obvious implication is that the Yavapai Orogeny post-dated the Wyoming-Superior collision on the eastern side of South Dakota and partially pre-dated, or at least was synchronous with, the final Wyoming-Superior closure on the western side of the state. In fact, Dahl and others (2005) interpret their older Geon 17 dates, the ca 1,780-1,785 Ma ages, to be associated with the 
Yavapai Orogeny to the south. More accurate dates of any available samples from within this region of the southern Trans-Hudson Orogen are vital to putting this issue to rest.

\section{Archean Model Ages and Granitoid Rocks of the Southern Trans-Hudson Internides}

An assessment of rock types intersected in drill holes in South Dakota clearly reveal a paucity of sea-floor deposits that one would expect to comprise the internides of the southern end of the Trans-Hudson Orogen (pl. 1). The vast majority of schists and associated rocks in South Dakota are located in the Black Hills Domain. With the exception of the Black Hills Precambrian outcrop area, the rock types intersected within the internides of this orogen are almost exclusively granitoids and felsic gneisses. A similar rock type observation, along with corresponding Archean Sm-Nd model ages led Lewry and others (1990) to propose a thinskinned tectonic model for that part of the Trans-Hudson Orogeny south of the Canadian border. In this model, it is proposed the Trans-Hudson internides are underthrust by the colliding Archean cratons, and erosion has removed most of the thin skin of Proterozoic internides.

Two related possibilities are that exotic microcontinents (Klasner and King, 1990; Nelson and others, 1993; Baird and others, 1996) or craton fragments derived from the adjacent cratons (Bickford and others, 2005) were caught up within and now comprise most of the suture zone. These possibilities relate to the thin-skinned tectonic model in that these cratonic fragments could have been underthrusted beneath the Trans-Hudson crust. Based on the little data available for rock types and model ages within the Trans-Hudson internides in the Dakotas, it is possible that one or two very long, narrow cratonic fragments are present within the suture and extend through most of North and South Dakota. The size and dimensions of such a fragment or fragments would be most easily explained with what is considered in this study to be a more local source for the fragments.

An isotopic study of the origin of the Archean Sask Craton by Bickford and others (2005) sheds a great deal of light on this issue. They measured ${ }^{208} \mathrm{~Pb} /{ }^{204} \mathrm{~Pb}$ ratios that are consistent with the elevated ${ }^{208} \mathrm{~Pb} /{ }^{204} \mathrm{~Pb}$ ratios observed in the Wyoming Craton rocks and that do not match the ratios observed in the Hearne and Superior Cratons. Although Bickford and others (2005) qualify this probable Wyoming Craton fragment as exotic, the term "exotic" seems misleading as it applies to the Trans-Hudson Orogen through the Dakotas because the Wyoming Craton is one of the bounding cratons in this region. Terminology aside, the interpretation of a long, narrow fragment of the Wyoming Craton, at least part of which would correspond to the Dakota Block of Baird and others (1996), being present within the Trans-Hudson Orogen in the Dakotas is a reasonable explanation for the geophysical, rock type, and model age observations within the Trans-Hudson internides, and is favored in this study.

\section{The Origin of the Southern Dakota Terrane}

Klasner and King (1986) suggested that the gravity low in southern South Dakota (fig. 3) was a granitic batholith. However, Klasner and King (1990) proposed that this gravity low and positive magnetic anomaly to the east were part of an accreted magmatic arc. Based on the 
geometry of Klasner and King's (1990) boundaries, presumably this proposed accreted magmatic arc was associated with the southern Trans-Hudson Orogeny, rather than the Yavapai Orogeny to the south.

The interpretation of the Southern Dakota Terrane defined in this study (pl. 1), which encompasses the southern part of Klasner and King's (1990) terrane IVa and most of their terrane IVb and IVc, is that it is a magmatic terrane. However, based on the geometry and location of this domain as interpreted in this study, it seems most likely that this terrane is related to the Yavapai Orogeny rather than the southern Trans-Hudson Orogeny.

In addition to the gravity low, several anomalous features are observed in this terrane. The anomalies include (1) the somewhat circular features seen along its north to northeastern margins in the geophysical data (in particular on the first horizontal derivative map of the gravity data in fig. 5), (2) the high present-day geothermal gradient that occurs spatially with the possible magmatic centers (Schoon and McGregor, 1974), (3) the strong positive magnetic anomaly that deforms the Superior Boundary Zone on the eastern margin, and (4) the Keya Paha Fault which trends toward but doesn't obviously connect with the boundary between the Southern Glennie Domain and Southern Flin Flon Belt.

The Southern Dakota Terrane is interpreted here to be mainly southern Trans-Hudson internides overprinted by events related to the Yavapai Orogeny, and thus a southern TransHudson Orogen boundary zone. However, an equally valid interpretation is that this domain consists of arc material accreted to the southern Trans-Hudson Orogen during the Yavapai Orogeny, or even that its northeastern section is a Trans-Hudson terrane and the rest is accreted Yavapai material. The alternative interpretations would mean the Yavapai boundary is actually within or at the northern margin of the Southern Dakota Terrane.

\section{Paleoproterozoic Uranium-Lead Dates in the Minnesota River Valley Subprovince}

Zircons from two rocks intersected in drill holes in and around the Sioux Block in South Dakota (pl. 1) have been dated by Van Schmus and others (2007). The 1,790 $\pm 13 \mathrm{Ma}$ U-Pb date from within the Jeffers Block(?) is from a microgranite and the $1,828 \pm 8 \mathrm{Ma} \mathrm{U}-\mathrm{Pb}$ date from within the Sioux Block is from a meta-rhyolite (table 1). Both samples have Archean model ages. Two additional volcanic rocks that yield 1,698 $\mathrm{Ma} \mathrm{Rb}-\mathrm{Sr}$ dates were intersected in drill holes near the Sioux Block boundary, one within the Montevideo Block, the other within the Sioux Block. The Rb-Sr dates give minimum ages, and thus cannot be ruled out as being associated with the event that produced the meta-rhyolite. All of these samples are located within approximately 7 miles of the inferred margin of the Sioux Block.

The proximity of these Paleoproterozoic rocks to the Sioux Block boundary suggests some reactivation along these boundaries during the Trans-Hudson Orogeny for the 1,828 Ma metarhyolite and the Trans-Hudson or Yavapai Orogeny for the 1790 \pm 13 Ma granite. Reactivation of the Minnesota River Valley Subprovince boundaries has been documented in Minnesota along the Yellow Medicine Shear Zone (Craddock and Magloughlin, 2005), though not to the degree that could trigger renewed igneous activity. However, localized Paleoproterozoic magmatic 
activity has been locally documented in the Minnesota River Valley Subprovince of Minnesota. For example, Southwick and others (1994) report a 1,792 Ma U-Pb date of a diorite from southwestern Minnesota, probably within the Jeffers Block (Jackson County, just north of the Iowa border). Goldich and others (1970) reported $\mathrm{Rb}-\mathrm{Sr}$ and $\mathrm{K}-\mathrm{Ar}$ ages of ca 1,750 Ma from a gabbro-granophyre complex called the Cedar Mountain Complex near Franklin in southern Minnesota. Doe and Delevaux (1980) measured a ca 1,840 Ma Rb-Sr and K-Ar dates on the section 28 granite located near Granite Falls in southwestern Minnesota.

The two additional volcanic rocks with the $\mathrm{Rb}-\mathrm{Sr}$ dates of 1,698 Ma sampled near the Sioux Block margin (table 1), if taken as accurate dates of crystallization, might indicate significant reactivation of the Minnesota River Valley Subprovince boundaries during the Yavapai Orogeny. If these dates reflect metamorphism, they still reflect a significant overprinting within the Minnesota River Valley Subprovince by the Yavapai Orogeny.

\section{Timing of Deposition of the Sioux Quartzite}

The Proterozoic Sioux Quartzite, a silica-cemented, supermature quartz arenite, may be one of the youngest Precambrian formations known within the Superior Craton in South Dakota. The Sioux Quartzite (pl. 1) extends northward as far as Beadle and Kingsbury Counties, southward to just south of the Nebraska border, and eastward into Minnesota and Iowa (Anderson, 1987; Houser, 1987). The quartzite is rare west of $101^{\circ}$ West longitude in South Dakota.

The estimated time of deposition of the Baraboo interval quartzites, of which the Sioux Quartzite is one, is 1,750 to 1,630 Ma (Holm and others, 1998). Detrital zircons within the Sioux Quartzite yield $\mathrm{Pb}-\mathrm{Pb}$ dates ranging from 1,729 to 1,782 Ma, which are Yavapai ages (Medaris and others, 2003; Czeck and Ormand, 2007). These dates indicate that the Sioux Quartzite is at least as young as 1,729 Ma. Goldich and others (1961) measured a K-Ar date on sericite from Sioux Quartzite pipestone of 1,200 Ma. This gives a minimum age for the Sioux Quartzite. The 1,200 Ma date may have been partially reset by magmatism associated with the Midcontinent Rift System, the oldest magmatism of which occurred at ca 1,109 to 1,106 Ma (Vervoort and others, 2007).

Of the supermature quartz arenites (quartzites) distributed from Canada to Arizona that parallel, but are located at variable distances northwest of Mazatzal terrane, the Sioux Quartzite appears to be most similar to the Barron Quartzite in its low degree of deformation and metamorphism. Some gentle "warping and tilting" have been documented within the Sioux Quartzite in South Dakota (Baldwin, 1949). Baldwin (1949) reports dips ranging from $0^{\circ}$ to $11^{\circ}$ with an average of $3^{\circ}$ to $4^{\circ}$ in outcrop, but dip directions are highly variable with directions both north and south. Localized, more apparent "tilting" has been documented in the Sioux Quartzite in southwestern Minnesota, typically on the order of $20^{\circ}$, less commonly of $30^{\circ}$ (Goldich and others, 1961), and as steep as $70^{\circ}$ at the New Ulm Quartzite quarries in Minnesota (Anderson, 1987; R. Anderson, oral commun., 2010). In Lyon County, Iowa, within a mile of the border with Minnehaha County, South Dakota (R. Anderson, oral commun., 2010), structural features noted in the quartzite are suggestive of a shear zone. 
The deformation of the supermature quartzites in Wisconsin date at about 1,630 Ma (Medaris and others, 2007), and the northern extent of the Mazatzal deformation front is placed between the deformed and undeformed supermature quartzites that lie within the Geon 17 crust in this region. To the southwest in Arizona through Colorado, metamorphism of these quartzites documents a Mazatzal deformation front within the Yavapai (Geon 17) Terrane (Jones and others, 2009).

In Arizona, New Mexico, Colorado, and Wisconsin where significant outcrops are found, these supermature quartzites are documented to unconformably overlie Yavapai-age (Geon 17) rhyolites and/or plutonic rocks (Holm and others, 1998; Jessup and others, 2006; Medaris and others, 2007; Jones and others, 2009). In northwest Iowa, a 1,782 Ma silicic volcanic rock, the Hull keratophyre, subcrops adjacent to (Anderson, 2006) and may underlie the Sioux Quartzite. In South Dakota, the Sioux Quartzite is known to overlie granitic rocks and possibly some rhyolites, but the age of these igneous rocks is not known. No contact metamorphism of the Sioux Quartzite by the underlying granite has been reported in this state. In Sanborn and Lake Counties in South Dakota, rhyolites and latites that are at least 1,700 Ma are spacially associated with the Sioux Quartzite, though it is unknown whether these volcanic rocks actually underlie the quartzite (pl. 1; see previous section on "Paleoproterozoic uranium-lead dates in the Minnesota River Valley Subprovince" for details regarding these volcanic rocks). Southwick and others (1986) note, too, that in Minnesota the Sioux Quartzite sedimentation was associated with "rhyolitic, ignimbritic volcanism."

Based on the few ages from detrital zircon within the Sioux Quartzite, this unit must be younger than ca 1,729 Ma. The 1,630 Ma folding and low-grade metamorphism of Baraboo interval quartzites in the Lake Superior region are the basis for the estimated minimum age of deposition of the Baraboo interval rocks. The lack of 1,630 Ma overprinting of Sioux Quartzite allows for the possibility that these particular quartzites could range to a younger depositional age than those in the Lake Superior region. At this point, perhaps the best minimum age constraint for the Sioux Quartzite is the Corson diabase, but radiometric dates of these intrusives have yet to be published.

As mentioned previously, the more recent models for the tectonic setting of these supermature quartzites include deposition into syntectonic extensional back-arc basins of highly weathered first generation sediments (Jones and others, 2009), and deposition into fore-arc basins of multi-cycle clastics (Carlson, 2007) or foreland basins on a stable cratonic margin with subdued topography (Craddock and McKiernan, 2007; Czeck and Ormand, 2007). The tectonicsetting model favored here for the Sioux Quartzite, which shows little deformation or thermal overprinting, and which overlies mainly Trans-Hudson terrane and the Superior Craton, is that of a foreland basin lying northwest of the main Mazatzal deformation front (Craddock and McKiernan, 2007; Czeck and Ormand, 2007). 


\section{CONCLUSIONS}

A significant part of the history of the assembly of the North American craton lies beneath the Phanerozoic-age cover in South Dakota. Unfortunately, the lack of high resolution geophysical data and high precision radiometric dating of available Precambrian rock cores in the Geological Survey Program's core facility in Vermillion, South Dakota, hinder further advancement of the understanding of the Precambrian basement in South Dakota and thus, of the Proterozoic period of assembly of the North American craton. The terrane map presented here (pl. 1) represents a new compilation of existing data and a reinterpretation of some aspects of the Precambrian basement, but too much of the story remains speculative. The biggest questions that remain from this work are (1) What is the present structure of the southern Trans-Hudson Orogen in South Dakota? and (2) What is the nature and location of the boundary between the Trans-Hudson Orogen and Yavapai Orogen?

Currently, the USArray program has its transportable array set up across South Dakota. USArray is a 15-year federal program to place a dense network of permanent and portable seismographs across the continental United States. Seismic data of the deep crust and upper mantle are being acquired that will aid in determination of deep structural and compositional variations beneath the North American continent. These data will lead to reinterpretation of what is presented here, but higher resolution aeromagnetic and crustal-level seismic data across South Dakota are needed to fully understand the structural variations and nature of the southern TransHudson and Yavapai terranes.

\section{ACKNOWLEDGEMENTS}

This manuscript was greatly improved through reviews by Val Chandler (Minnesota Geological Survey) and Ray Anderson, Bill Bunker, Caroline Davis, and David Pals (Iowa Geologic and Water Survey). 


\section{REFERENCES}

Anderson, R.R., 1987, Precambrian Sioux Quartzite at Gitchie Manitou State Preserve, Iowa, $\underline{\text { in }}$ Biggs, D.L., ed., Geological Society of America Centennial Field Guide, v. 3, p. 77-80. 2006, Geology of the Precambrian surface of Iowa and surrounding area: Iowa Geologic and Water Survey Open File Map OFM-06-7, scale 1:1,000,000.

Annesley, I.R., Madore, C., and Portella, P., 2005, Geology and thermotectonic evolution of the western margin of the Trans-Hudson Orogen: Evidence from the eastern sub-Athabasca basement, Saskatchewan: Canadian Journal of Earth Sciences, v. 42, p. 573-597.

Baird, D.J., Nelson, K.D., Knapp, J.H., Walters, J.J., and Brown, L.D., 1996, Crustal structure and evolution of the Trans-Hudson Orogen: Results from seismic reflection profiling: Tectonics, v. 15, no. 2, p. 416-426.

Baldwin, B., 1949, A preliminary report on the Sioux Quartzite: South Dakota Geological Survey Report of Investigations 63, 34 p.

Bickford, M.E., Mock, T.D., Steinhart, W.E., III, Collerson, K.D., and Lewry, J.F., 2005, Origin of the Archean Sask Craton and its extent within the Trans-Hudson Orogen: Evidence from $\mathrm{Pb}$ and $\mathrm{Nd}$ isotopic compositions of basement rocks and post-orogenic intrusions: Canadian Journal of Earth Sciences, v. 42, p. 659-684.

Bickford, M.E., Wooden, J.L., and Bauer, R.L., 2006, SHRIMP study of zircons from Early Archean rocks in the Minnesota River Valley: Implications for the tectonic history of the Superior Province: Geological Society of America Bulletin, v. 118, no. 1/2, p. 94-108.

Bolin, E.J., and Petsch, B.C., 1954, Well logs in South Dakota east of Missouri River: South Dakota Geological Survey Report of Investigations 75, 95 p.

Carlson, M.P., 2007, Precambrian accretionary history and Phanerozoic structures - A unified explanation for the tectonic architecture of the Nebraska region, USA: Geological Society of America Memoir 200, p. 321-326.

Chandler, V.W., Boerboom, T.J., and Jirsa, M.A., 2007, Penokean tectonics along a promontory-embayment margin in east-central Minnesota: Precambrian Research, v. 157, p. 26-49.

Chasten, L.E., 2009, Electron microprobe (ultrachron) geochronology of Monazite from the Homestake Iron Formation, Lead, the Black Hills, South Dakota, U.S.A.: Rapid City, S. Dak., South Dakota School of Mines and Technology, M.S. thesis, 97 p.

Cooper, G.R.J., and Cowan, D.R., 2006, Enhancing potential field data using filters based on local phase: Computers \& Geosciences, v. 32, p. 1585-1591.

Craddock, J.P., and Magloughlin, J.F., 2005, Calcite strains, kinematic indicators, and magnetic flow fabric of Proterozoic pseudotachylyte swarm, Minnesota River Valley, USA: Tectonophysics, v. 402, p. 153-168.

Craddock, J.P., and McKiernan, A.W., 2007, Tectonic implications of finite strain variations in Baraboo-interval quartzites (ca. 1700 Ma), Mazatzal Orogen, Wisconsin and Minnesota, USA: Precambrian Research, v. 156, p. 175-194.

Czeck, D.M., and Ormand, C.J., 2007, Geometry and folding history of the Baraboo syncline: Implications for the Mazatzal Orogeny in the north-central U.S.: Precambrian Research, v. 157 , p. 203-213. 
Dahl, P.S., 2010, Precambrian geochronology of the Black Hills, South Dakota: Past results and future directions, in Terry, M.P., Duke, E.F., and Tielke, J.A., eds., Geologic field trips in the Black Hills region, South Dakota: Rapid City, S. Dak., South Dakota School of Mines and Technology Bulletin 21, p. 187-201.

Dahl, P.S., and Frei, R., 1998, Step-leaching Pb-Pb dating of inclusion-bearing garnet and staurolite, with implications for Early Proterozoic tectonism in the Black Hills collisional orogen, South Dakota, United States: Geology, v. 26, p. 111-114.

Dahl, P.S., Terry, M.P., Jercinovic, M.J., Williams, M.L., Hamilton, M.A., Foland, K.A., Clement, S.M., and Friberg, L.M., 2005, Electron probe (ultrachron) microchronometry of metamorphic monazite: Unraveling the timing of polyphase thermotectonism in easternmost Wyoming Craton (Black Hills, South Dakota): American Mineralogist, v. 90, p. 1712-1728.

Doe, R.R., and Delevaux, M.H., 1980, Lead-isotope investigations in the Minnesota River Valley - Late tectonic and posttectonic granites: Geological Society of America Special Paper 182, p. 105-112.

Dutch, S.I., and Nielsen, P.A., 1990, The Archean Wyoming province and its relations with adjacent Proterozoic provinces, in Lewry, J.F., and Stauffer, M.R., eds., The Early Proterozoic Trans-Hudson Orogen of North America: Geological Association of Canada Special Paper 37, p. 287-300.

Geological Survey Program, 2010, Lithologic logs database: South Dakota Department of Environment and Natural Resources. Available from http://www.sddenr.net/lithdb/ [Accessed 2005-2009].

Goldich, S.S., Hedge, C.E., and Stern, T.W., 1970, Age of the Morton and Montevideo gneisses and related rocks, southwestern Minnesota: Geological Society of America Bulletin, v. 81, p. 3671-3696.

Goldich, S.S., Lidiak, E.G., Hedge, C.E., and Walthall, F.G., 1966, Geochronology of the Midcontinent region, United States, [Part 2], northern area: Journal of Geophysical Research, v. 71, issue 22, p. 5389-5408.

Goldich, S.S., Nier, A.O., Baadsgaard, H., Hoffman, J.H., and Krueger, H.W., 1961, The Precambrian geology and geochronology of Minnesota: Minnesota Geological Survey Bulletin 71, 193 p.

Gosselin, D.C., Papike, J.J., Zartman, R.E., Peterman, Z.E., and Laul, J.C., 1988, Archean rocks of the Black Hills, South Dakota: Reworked basement from the southern extension of the Trans-Hudson Orogen: Geological Society of America Bulletin, v. 100, p. 1244-1259.

Green, A.G., Cumming, G.L., and Cedarwell, D., 1979, Extension of the Superior-Churchill boundary zone into southern Canada: Canadian Journal of Earth Sciences, v. 16, p. 1691-1701.

Green, A.G., Weber, W., and Hajnal, Z., 1985, Evolution of Proterozoic terrains beneath the Williston Basin: Geology, v. 13, p. 624-628.

Holm, D., Schneider, D., and Coath, C.D., 1998, Age and deformation of Early Proterozoic quartzites in the southern Lake Superior region: Implications for extent of foreland deformation during final assembly of Laurentia: Geology, v. 26, no. 10, p. 907-910.

Holm, D.K., 1999, A geodynamic model for Paleoproterozoic post-tectonic magma genesis in the southern Trans-Hudson (Black Hills, South Dakota) and Penokean (southern Lake Superior) Orogens: Rocky Mountain Geology, v. 34, p. 183-194. 
Holm, D.K., Anderson, R., Boerboom, T.J., Cannon, W.F., Chandler, V., Jirsa, M., Miller, J., Schneider, D.A., Schulz, K.J., and Van Schmus, W.R., 2007, Reinterpretation of Paleoproterozoic accretionary boundaries of the north-central United States based on a new aeromagnetic-geologic compilation: Precambrian Research, v. 157, p. 71-79.

Houser, B.B., 1987, Southwestern bounding fault of the Sioux Quartzite, South Dakota and Nebraska: U.S. Geological Survey Open-File Report 87-626, 11 p.

Houston, R.S., 1993, Late Archean and Early Proterozoic geology of southeastern Wyoming: Wyoming Geological Survey Memoir 5, p. 79-116.

Hull, A., Holm, D., and Schneider, D., 2009, Preliminary results of ${ }^{40} A r{ }^{39}$ Ar thermochronology from the central Yavapai Province, U.S. mid-continent, in Institute on Lake Superior Geology Proceedings, Ely, Minn., May 2009, Part 1, Program and Abstracts, v. 55, p. 44-45.

Jessup, M.J., Jones, J.V., III, Karlstrom, K.E., Williams, M.L., Connelly, J.N., and Heizler, M.T., 2006, Three Proterozoic orogenic episodes and an intervening exhumation event in the Black Canyon of the Gunnison region, Colorado: Journal of Geology, v. 114, p. 555-576.

Jones, A.G., and Savage, P.J., 1986, North American central plains anomaly goes east: Geophysical Research Letters, v. 13, p. 685-688.

Jones, J.V., III, Connelly, J.N., Karlstrom, K.E., Williams, M.L., and Doe, M.F., 2009, Age, provenance, and tectonic setting of Paleoproterozoic quartzite successions in the southwestern United States: Geological Society of America Bulletin, v. 121, no. 1/2, p. 247-264.

Karlstrom, K.E., and Bowring, S.A., 1988, Early Proterozoic assembly of tectonstratigraphic terranes of southwestern North America: Journal of Geology, v. 96, p. 561-576.

Klasner, J.S., and King, E.R., 1986, Precambrian basement geology of North and South Dakota: Canadian Journal of Earth Sciences, v. 23, p. 1083-1102.

1990, A model for tectonic evolution of the Trans-Hudson Orogen in North and South Dakota, in Lewry, J.F., and Stauffer, M.R., eds., The Early Proterozoic Trans-Hudson Orogen of North America: Geological Association of Canada Special Paper 37, p. 271-285.

Kucks, R.P., and Hill, P.L., 2002, South Dakota aeromagnetic and gravity maps and data: A web site for distribution of data: U.S. Geological Survey Open-File Report 02-341, http://pubs.usgs.gov/of/2002/ofr-02-0341/ [Accessed 2007].

Lee, K.Y., 1957, Some hydrothermal effects in a volcanic rock from a well boring, Sanborn County, South Dakota: Proceedings of the South Dakota Academy of Science, XXXVI, p. 117-122.

Lewry, J.F., and Collerson, K.D., 1990, The Trans-Hudson Orogen: Extent, subdivisions, and problems, in Lewry, J.F., and Stauffer, M.R., eds., The Early Proterozoic Trans-Hudson Orogen of North America: Geological Association of Canada Special Paper 37, p. 1-14.

Lewry, J.F., Thomas, D.J., Macdonald, R., and Chiarenzelli, J., 1990, Structural relations in accreted terranes of the Trans-Hudson Orogen, Saskatchewan: Telescoping in a collisional regime?: Geological Association of Canada Special Paper 37, p. 75-94.

Lidiak, E.G., 1971, Buried Precambrian rocks of South Dakota: Geological Society of America Bulletin, v. 82, p. 1411-1420.

Lisenbee, A.L., 2010, The Black Hills uplift in its regional context, in Terry, M.P., Duke, E.F., and Tielke, J.A., eds., Geologic field trips in the Black Hills region, South Dakota: Rapid City, S. Dak., South Dakota School of Mines and Technology Bulletin 21, p. 202-207. 
McCombs, J.A., Dahl, P.S., and Hamilton, M.A., 2004, U-Pb ages of Neoarchean granitoids from the Black Hills, South Dakota: Implications for crustal evolution in the Archean Wyoming Province: Precambrian Research, v. 130, p. 161-184.

McCormick, K.A., 2010, Elevation contour map of the Precambrian surface of South Dakota: South Dakota Geological Survey General Map 11, scale 1:500,000.

McGinnis, L.D., Wolf, M.G., Kohsmann, J.J., and Ervin, C.P., 1979, Regional free air gravity anomalies and tectonic observations in the United States: Journal of Geophysical Research, v. 84, no. B2, p. 591-601.

Medaris, L.G., Jr., Singer, B.S., Dott, R.H., Jr., Naymark, A., Johnson, C.M., and Schott, R.C., 2003, Late Paleoproterozoic climate, tectonics, and metamorphism in the southern Lake Superior region and proto-North America: Evidence from Baraboo interval quartzites: The Journal of Geology, v. 111, p. 243-257.

Medaris, L.G., Jr., Van Schmus, W.R., Loofboro, J., Stonier, P.J., Zhang, X., Holm, D.K., Singer, B.S., and Dott, R.H., Jr., 2007, Two Paleoproterozoic (Statherian) siliciclastic metasedimentary sequences in central Wisconsin: The end of the Penokean Orogeny and cratonic stabilization of the southern Lake Superior region: Precambrian Research, v. 157, p. 188-202.

Nelson, K.D., Baird, D.J., Walters, J.J., Hauck, M., Brown, L.D., Oliver, J.E., Ahern, J.L., Hajnal, Z., Jones, A.G., and Sloss, L.L., 1993, Trans-Hudson Orogen and Williston Basin in Montana and North Dakota: New COCORP deep-profiling results: Geology, v. 21, p. 447-450.

Nichols, T.C., Collins, D.S., and Swolfs, H.S., 1989, Seismic profiling of geologic structures near Pierre, South Dakota: U.S. Geological Survey Open-File Report 89-224, 18 p.

Peterman, Z.E., and Goldich, S.S., 1982, Archean rocks of the Churchill Basement, Williston Basin, North Dakota: International Williston Basin Symposium, 4 ${ }^{\text {th }}$, Regina, Sask., Saskatchewan Geological Society Special Publication 6, p. 11-12.

Petsch, B.C., 1967, Vertical-intensity magnetic map of South Dakota, ground magnetometer survey: South Dakota Geological Survey Mineral Resources Investigations 4.

Redden, J.A., and DeWitt, E., 2008, Maps showing geology, structure, and geophysics of the central Black Hills, South Dakota: U.S. Geological Survey Scientific Investigations Map 2777, 44 p., 2 map sheets, scale 1:100,000.

Redden, J.A., Peterman, Z.E., Zartman, R.E., and DeWitt, E., 1990, U-Th-Pb geochronology and preliminary interpretation of Precambrian tectonic events in the Black Hills, South Dakota, in Lewry, J.F., and Stauffer, M.R., eds., The Early Proterozoic Trans-Hudson Orogen of North America: Geological Association of Canada Special Paper 37, p. 229-251.

Reed, J.C., Jr., ed., Ball, T.T., Farmer, G.L., and Hamilton, W.B., 1993, Chapter 7, A broader view, in Reed, J.C., Jr., Bickford, M.E., Houston, R.S., Link, P.K., Rankin, D.W., Sims, P.K., and Van Schmus, W.R., eds., The geology of North America, Precambrian: Conterminous U.S.: The Geological Society of America, v. C-2, p. 597-636.

Richards, J.R., Baron, D.M., and Goldich, S.S., 1986, Age of the basement staurolite-biotite schist of northeastern South Dakota: U.S. Geological Survey Bulletin 1622, p. 65-75.

Schmitz, M.D., Bowring, S.A., Southwick, D.L., Boerboom, T.J., and Wirth, K.R., 2006, Highprecision U-Pb geochronology in the Minnesota River Valley Subprovince and its bearing on the Neoarchean to Paleoproterozoic evolution of the southern Superior Province: Geological Society of America Bulletin, v. 118, p. 82-93. 
Schoon, R.A., and McGregor, D.J., 1974, Geothermal potentials in South Dakota: South Dakota Geological Survey Report of Investigations 110, 76 p.

Schulz, K.J., and Cannon, W.F., 2007, The Penokean Orogeny in the Lake Superior region: Precambrian Research, v. 157, p. 4-25.

Sims, P.K., 1985, Precambrian basement map of the Midcontinent, U.S.A.: U.S. Geological Survey Open-File Report 85-0604, scale 1:1,000,000.

Sims, P.K., ed., Anderson, J.L., Bauer, R.L., Chandler, V.W., Hanson, G.N., Kalliokoski, J., Morey, G.B., Mudrey, M.G., Jr., Ojakangas, R.W., Peterman, Z.E., Schulz, K.J., Shirey, S.B., Smith, E.I., Southwick, D.L., Van Schmus, W.R., and Weiblen, P.W., 1993, Chapter 2, The Lake Superior region and the Trans-Hudson Orogen, in Reed, J.C., Jr., Bickford, M.E., Houston, R.S., Link, P.K., Rankin, D.W., Sims, P.K., and Van Schmus, W.R., eds., The geology of North America, Precambrian: Conterminous U.S.: The Geological Society of America, v. C-2, p. 11-120.

Sims, P.K., Finn, C.A., and Rystrom, V.L., 2001, Preliminary Precambrian basement map showing geologic-geophysical domains, Wyoming: U.S. Geological Survey Open-File Report 01-199, 9 p., 2 pls.

Sims, P.K., O’Neill, J.M., Bankey, V., and Anderson, E., 2004, Precambrian basement geologic map of Montana - an interpretation of aeromagnetic anomalies: U.S. Geological Survey Scientific Investigations Map 2829, version 1.0, scale 1:1,000,000.

Sims, P.K., and Peterman, Z.E., 1981, Archean rocks in the southern part of the Canadian Shield - a review: Special Publications of the Geological Society of Australia, v. 7, p. 85-98.

1986, Early Proterozoic Central Plains Orogen: A major buried structure in the northcentral United States: Geology, v. 14, p. 488-491.

Sims, P.K., Peterman, Z.E., Hildenbrand, T.G., and Mahan, S., 1991, Precambrian basement map of the Trans-Hudson Orogen and adjacent terranes, northern Great Plains, U.S.A.: U.S. Geological Survey Miscellaneous Investigations Series Map I-2214, 53 p., 1 map sheet, scale $1: 1,000,000$.

Sklar, P.J., 1982, Petrologic, petrographic and paleotectonic investigation of Precambrian mafic intrusives in eastern South Dakota: Iowa City, Iowa, University of Iowa, M.S. thesis, 98 p.

Southwick, D.L., and Chandler, V.W., 1996, Block and shear-zone architecture of the Minnesota River Valley Subprovince: Implications for the late Archean accretionary tectonics: Canadian Journal of Earth Sciences, v. 33, p. 831-847.

Southwick, D.L., Morey, G.B., and Mossler, J.H., 1986, Fluvial origin of the lower Proterozoic Sioux Quartzite, southwestern Minnesota: Geological Society of America Bulletin, v. 97, p. 1432-1441.

Southwick, D.L., Peterman, Z.E., Snee, L.W., and Van Schmus, W.R., 1994, Assorted geochronologic studies of Precambrian terranes in Minnesota: A potpourri of timely information, in Southwick, D.L., ed., Short contributions to the geology of Minnesota: Minnesota Geological Survey Report of Investigations, v. 43, p. 1-19.

Steece, F.V., 1962, Precambrian basement rocks of South Dakota: Proceedings of the South Dakota Academy of Science, XLI, p. 51-56.

Tvrdik, T.N., 1983, Petrology of the Precambrian basement rocks of the Matlock project cores: Northwestern Iowa: Iowa City, Iowa, University of Iowa, M.S. thesis, 113 p.

Van Schmus, W.R., 1980, Chronology of igneous rocks associated with the Penokean Orogeny in Wisconsin: Geological Society of America Special Paper 182, p. 159-168. 
Van Schmus, W.R., Bickford, M.E., eds., Anderson, J.L., Bender, E.E., Anderson, R.R., Bauer, P.W., Robertson, J., Bowring, S.A., Condie, K.C., Denison, R.E., Gilbert, M.C., Grambling, J.A., Mawer, C.K., Shearer, C.K., Hinze, W.J., Karlstrom, K.E., Kisvarsanyi, E.B., Lidiak, E.G., Reed, J.C., Jr., Sims, P.K., Tweto, O., Silver, L.T., Treves, S.B., Williams, M.L., and Wooden, J.L., 1993, Chapter 4, Transcontinental Proterozoic provinces, in Reed, J.C., Jr., Bickford, M.E., Houston, R.S., Link, P.K., Rankin, D.W., Sims, P.K., and Van Schmus, W.R., eds., The geology of North America, Precambrian: Conterminous U.S.: The Geological Society of America, v. C-2, p. 171-334.

Van Schmus, W.R., Schneider, D.A., Holm, D.K., Dodson, S., and Nelson, B.K., 2007, New insights into the southern margin of the Archean-Proterozoic boundary in the north-central United States based on U-Pb, Sm-Nd, and Ar-Ar geochronology, in Holm, D.K., Schneider, D., and Chandler, V.W., eds., Proterozoic tectonic and crustal evolution of the Upper Great Lakes region, North America: Precambrian Research, v. 157, issues 1-4, p. 80-105.

Vervoort, J.D., Wirth, K., Kennedy, B., Sandland, T., and Harpp, K.S., 2007, The magmatic evolution of the Midcontinent rift: New geochronologic and geochemical evidence from felsic magmatism: Precambrian Research, v. 157, p. 235-268.

Walker, R.J., Hanson, G.N., Papike, J.J., and O’Neil, J.R., 1986, Nd, O, and Sr isotopic constraints on the origin of Precambrian rocks, southern Black Hills, South Dakota: Geochimica et Cosmochimica Acta, v. 50, p. 2833-2846.

White, D.J., Thomas, M.D., Jones, A.G., Hope, J., Németh, B., and Hajnal, Z., 2005, Geophysical transect across a Paleoproterozoic continent-continent collision zone: The Trans-Hudson Orogen: Canadian Journal of Earth Sciences, v. 42, p. 385-402.

Wilcox, K.H., 1991, Geological relationships in the Wood Lake area, Tabbernor Fault Zone, Saskatchewan, in Summary of investigations 1991, Saskatchewan Geological Survey: Saskatchewan Energy and Mines Miscellaneous Report 91-4, p. 135-143.

Williams, H.R., 1990, Subprovince accretion tectonics in the south-central Superior Province: Canadian Journal of Earth Sciences, v. 27, p. 570-581.

Windom, K.E., Van Schmus, W.R., Seifert, K.E., Wallin, E.T., and Anderson, R.R., 1993, Archean and Proterozoic tectono-magmatic activity along the southern margin of the Superior Province in northwestern Iowa, United States: Canadian Journal of Earth Sciences, v. 30, p. 1275-1285.

Yaghubpur, A., 1979, Preliminary geologic appraisal and economic aspects of the Precambrian basement of Iowa: Iowa City, Iowa, University of Iowa, Ph.D. dissertation, 294 p. 